This item was submitted to Loughborough's Research Repository by the author.

Items in Figshare are protected by copyright, with all rights reserved, unless otherwise indicated.

\title{
Can the consumption-wealth ratio predict housing returns? Evidence from OECD countries
}

\author{
PLEASE CITE THE PUBLISHED VERSION
}

http://dx.doi.org/10.1111/1540-6229.12135

\section{PUBLISHER}

(C) American Real Estate and Urban Economics Association. Published by Wiley

\section{VERSION}

AM (Accepted Manuscript)

\section{PUBLISHER STATEMENT}

This work is made available according to the conditions of the Creative Commons Attribution-NonCommercialNoDerivatives 4.0 International (CC BY-NC-ND 4.0) licence. Full details of this licence are available at: https://creativecommons.org/licenses/by-nc-nd/4.0/

\section{LICENCE}

CC BY-NC-ND 4.0

\section{REPOSITORY RECORD}

Caporale, Guglielmo Maria, Ricardo M. Sousa, and Mark Wohar. 2019. "Can the Consumption-wealth Ratio Predict Housing Returns? Evidence from OECD Countries”. figshare. https://hdl.handle.net/2134/26061. 


\title{
Can the Consumption-Wealth Ratio Predict Housing Returns? Evidence from OECD Countries
}

\author{
Guglielmo Maria Caporale* $\quad$ Ricardo M. Sousa ${ }^{\$} \quad$ Mark E. Wohar ${ }^{\dagger}$
}

November 15, 2014

\begin{abstract}
We use a representative consumer model to analyse the relation between the transitory deviations of consumption from its common trend with aggregate wealth and labour income, cay, and the housing risk premium. The evidence based on data for 15 OECD countries shows that, if financial and housing assets are seen as complements, investors will temporarily allow consumption to rise when they expect a rise in future housing returns. By contrast, if housing assets are treated as substitutes for financial assets, consumption will be reduced.
\end{abstract}

JEL classification: E21, E44, D12.

Keywords: consumption, wealth, stock returns, housing returns, OECD countries.

${ }^{*}$ Centre for Empirical Finance, Brunel University, London UB8 3PH, UK. Email: GuglielmoMaria.Caporale@brunel.ac.uk.

\$ University of Minho, Department of Economics and Economic Policies Research Unit (NIPE), Campus of Gualtar, 4710-057 - Braga, Portugal; London School of Economics, LSE Alumni Association, Houghton Street, London WC2 2AE, United Kingdom. E-mails: rjsousa@eeg.uminho.pt, rjsousa@alumni.lse.ac.uk.

† University of Nebraska-Omaha, College of Business Administration, Department of Economics, Mammel Hall 332S, 6708 Pine Street, Omaha, NE 68182-0048, USA. E-mail: mwohar@unomaha.edu. 


\section{Introduction}

Stock return predictability has been extensively documented in the empirical finance literature (Fama and French; 1988; Campbell and Shiller; 1988) and an important line of investigation has looked into the relationship between wealth and macroeconomic aggregates and the extent to which it captures the future dynamics of the equity risk premium (Lettau and Ludvigon, 2001; Sousa, 2010a).

More recently, as a result of the developments in sovereign bond markets, some authors have started to revisit the issue of the predictability of the bond risk premium (Ludvigson and Ng, 2009; Thornton and Valente, 2009, 2012) or to focus on the determinants of the risk premium associated with government bonds (Sousa, 2010b, 2012a).

When it comes to housing, the regional or country level and cross-country studies have typically focused on the macroeconomic determinants of housing prices (Leung, 2004; Hwang and Quigley, 2006; Kallberg et al., 2014), its impact on collateral constraints (Jin et al., 2012; Ren and Yuan, 2014) and its relationship with consumption via the so-called wealth effects (Ando and Modigliani, 1963; Ludvigson and Steindel, 1999; Lettau and Ludvigson, 2004; Case et al., 2005, 2011).

While the abovementioned body of research establishes an important link between housing wealth and consumption and generally agrees that an increase in housing wealth leads to higher consumption, a new strand of the empirical finance literature has incorporated features of the housing market to explain the time-varying nature of risk premium (Lustig and Van Nieuwerburgh, 2005; Yogo, 2006; Leung et al., 2006; Leung, 2007; Piazzesi et al., 2007; Sousa, 2010a; Pakos, 2011; Ren et al., 2014).

Yet, housing returns appear to be understudied. Thus, this paper extends the previous research and focuses on the housing risk premium. More specifically: i) we follow the influential paper by Lettau and Ludvigson (2001), recently extended by Sousa (2010a), and assess the joint dynamics of consumption, wealth, income and housing returns, as captured by the consumption-wealth ratio (labelled as cay); ii) we investigate the ability of cay to track time-variation in the future housing risk premium; and iii) we make inferences about the degree of substitutability or complementarity between financial and housing assets implied by the relationship between cay and housing returns.

Using data for 15 industrialised countries, we show that cay predicts future housing returns: it is statistically significant for a large number of countries and its point 
estimate is large in magnitude. Moreover, it explains a sizeable percentage of the variation in future real returns, especially at long horizons, specifically 6\% (Italy), 7\% (Finland), 8\% (Denmark), 11\% (Australia), 14\% (Japan), 23\% (UK), 25\% (Belgium), 49\% (Canada) and 56\% (Spain) of the real housing return over the next eight quarters. By contrast, its forecasting power is poor for countries such as France, Germany, Ireland and the US.

The empirical findings also suggest that in Belgium, Canada, Denmark, Finland, Ireland, Italy, Japan, Spain, Sweden, the UK and the US agents allow consumption to rise above its equilibrium relationship with asset wealth and labour income when they expect housing returns to increase in the future, that is, financial and housing assets are complements, whilst in France, Germany and the Netherlands they appear to be substitutes.

When investigating the robustness of our results, we find that: (i) the predictive ability of cay remains unchanged when we add other control variables to our regressions; and (ii) the models that include cay outperform other benchmark models. We also find that, in some countries, agents seem to have myopic behaviour and suffer from money illusion, while in others they appear to use housing assets as a hedge against the inflation risk, as also suggested by Blenman (1990).

Finally, we assess the country characteristics that help to explain the heterogeneity that we observe in the predictive ability of the consumption-wealth ratio. We show that variation in macroeconomic factors (such as the real GDP per capita, the real GDP growth rate and the inflation rate), money market conditions (as captured by the risk-free rate) and easiness of credit access (which is proxied by the leverage ratio) account for the cross-country differences in the power that cay displays at forecasting future housing risk premium. By contrast, the size of the country does not appear to play an important role.

The paper is organised as follows. Section 2 briefly reviews the relevant literature. Section 3 describes the theoretical framework and the empirical methodology. Section 4 discusses the results of the forecasting regressions for real and excess housing returns. Section 5 focuses on robustness. Section 6 concludes.

\section{A Brief Review of the Literature}

The seminal work on stock return predictability have highlighted the importance of market inefficiencies (Fama and French, 1996) or time-varying 
investment opportunities (Constantinides, 1990) in explaining why expected excess stock returns vary with the business cycle. In this context, a relevant strand of the empirical finance literature has analysed the joint dynamics of consumption, wealth and a series of macroeconomic aggregates and investigated their predictive ability for future stock returns (Lettau and Ludvigon, 2001; Sousa, 2010a, 2012a). ${ }^{1}$

Following the financial turmoil of 2008-2009 and the subsequent sovereign debt crisis, the predictability of the bond risk premium has become a key question and has attracted the attention of academics, central banks and policy makers (Ludvigson and Ng, 2009; Thornton and Valente, 2009, 2012; Sousa, 2012a). ${ }^{2}$ Rapach and Wohar (2009) consider the case of Epstein-Zin-Weil preferences and find that US investors display sizeable mean intertemporal hedging demands for domestic stocks and small ones for foreign stocks and bonds. By relating the behaviour of bond yields to a set of macro-financial variables, these studies have opened new avenues for assessing how changes in public debt affect consumers' expectations about future returns and how these, in turn, are mapped into their spending patterns (Afonso and Sousa, 2011; Sousa, 2010b, 2012a).

As for housing, the focus has been mostly on assessing its macroeconomic drivers, such as business cycle fluctuations, income growth, industrial production or employment rate (Leung, 2004; Hwang and Quigley, 2006; Kallberg et al., 2014), its effect on collateral constraints (Jin et al., 2012; Ren and Yuan, 2014) or the wealth effects that it generates (Ando and Modigliani, 1963; Ludvigson and Steindel, 1999; Lettau and Ludvigson, 2004; Case et al., 2005, 2011). Using a micro-founded aggregate Euler equation for consumption and aggregate time-series data, Iacoviello (2004) challenges the common belief that rising housing prices have kept consumption growth high in the nineties, as the elasticity of consumption to house prices is generally low. He highlights that when households have liquidity constraints and value current consumption a lot, an increase in house prices raises borrowing and consumption more than proportionally and thus has a positive impact on aggregate demand. Using aggregate consumption and wealth data for the US, Benjamin et al. (2004) find that the marginal propensity to consume from housing wealth is significant and higher than that of financial wealth. Case et al. (2005) gather data for the US states and a set of foreign

\footnotetext{
${ }^{1}$ Rapach et al. (2005) show that interest rates are the most reliable predictor of stock returns, while Jordan et al. (2014) emphasize the importance of the trade links.

${ }^{2}$ For an analysis of the importance of inflation uncertainty in the European Monetary Union, see Caporale and Kontonikas (2009).
} 
countries and uncover significant wealth effects on consumption of both types of wealth, those of housing wealth being substantially larger. Chen and Leung (2007) show that when economic agents face binding collateral constraint, the joint dynamics of house prices and output exhibits similarities with a regime-switching model. Case et al. (2011) extend the panel of US states to include the volatility in asset markets during 2008-2009. They find that while housing wealth effects remain stronger than financial wealth effects, asymmetry is no longer present. Therefore, the effects on consumption of declines in housing wealth in reducing consumption are at least as large as the effects of increases in housing wealth.

Other studies have looked at the linkages between consumption and housing wealth using household data. For instance, Campbell and Cocco (2007) show that the largest housing wealth effect is found for older homeowners, while the smallest wealth effect is observed for younger renters. Attanasio et al. (2009) explore three main competing theories, namely: (i) an unexpected increase in house prices raises households' wealth, and, thus, optimal consumption (Muellbauer and Murphy, 1990); (ii) both consumption and wealth are determined by revisions to expected future income (King, 1990; Pagano, 1990); and (iii) house price gains increase housing collateral, being specially important to young households who are more likely to be creditconstrained (Aoki et al., 2001). They find evidence corroborating the idea that common causality is the most important explanation for the co-movement between consumption and house price growth. Bostic et al. (2009) assemble a unique matched sample from the Survey of Consumer Finance and the Consumer Expenditure Survey and estimate the financial and housing wealth effects on consumption. They suggest that housing wealth elasticities are typically three times as large as financial wealth elasticities and consumption propensities are also substantially different for credit constrained and noncredit constrained households. Cho (2011) shows that, despite the weak link between housing price and consumption at the aggregate level, there is a positive wealth effect of homeowners associated with rising home prices which may be offset by a negative wealth effect of non-homeowners.

While the abovementioned studies generally agree that an increase in housing wealth leads to higher consumption, a new strand of the empirical finance literature has started to incorporate features of the housing market to explain the time-varying nature of risk premium. Kallberg et al. (2002) assess jointly the regime shifts in equity and real estate markets. Lustig and van Nieuwerburgh (2005) show that the housing collateral 
ratio plays an important role by shifting the conditional distribution of asset prices and consumption growth. Yogo (2006) and Piazzesi et al. (2007) focus on the importance of non-separability of preferences, in particular, by looking at the relationship between durable and nondurable consumption and between housing and non-housing consumption, respectively, and arguing that it captures the countercyclical dynamics of the equity premium. Leung et al. (2006) argue that the observed house price dispersion is a symptom of inefficiency of the housing market. Leung (2007) builds a dynamic general equilibrium model with fully rational agents and shows that the optimal weight of housing in the investor's portfolio depends on the cross-correlation of assets. Sousa (2010a) distinguishes between financial wealth shocks (which are typically transitory) and housing wealth fluctuations (which are characterized by strong persistence). Therefore, the wealth composition of risk is an important driver of stock returns. Pakos (2011) argues that there is an important non-homotheticity in preferences in the presence of both income and substitution effects. Moreover, homotheticity leads to a relevant statistical bias in the estimates of the intratemporal and intertemporal substitutions due the role played by durable goods. Quijano (2012) provides a refined version of the consumption-wealth ratio, where wealth equals the sum of the market values of stock of housing, equity, debt, and labor income. The author shows that the consumption-wealth ratio helps accounting for the time-varying nature of future stock returns. Ren et al. (2014) argue that because durable goods assets and housing wealth provide utility from the ownership right and have distributions across income groups and liquidity characteristics that are different from financial wealth, one needs to account for the role of household capital (i.e. the sum of housing wealth and durable goods) when forecasting risk premium.

Despite this, there is a lack of studies dealing specifically with the issue of predictability of housing risk premium, which is somewhat surprising. First, the 20072009 financial turmoil has clearly shown how strong the linkages between the housing sector, the financial system and, ultimately, the macroeconomy are. ${ }^{3}$ Second, its severity

\footnotetext{
${ }^{3}$ Wealth dynamics are also crucial for the conduct of monetary policy (Sousa, 2010c), for the nexus between monetary stability and financial markets' stability (Granville and Mallick, 2009; Castro, 2011; Cover and Mallick, 2012), for the implementation of fiscal policy (Agnello et al., 2012, 2013), and because of their macroeconomic impact (Rafiq and Mallick, 2008; Mallick and Mohsin, 2007, 2010; Agnello and Schuknecht, 2011), as well as the role of market segmentation (Blenman, 1991). In the specific case of housing, it can also be used to hedge against unfavourable wealth shocks (Sousa, 2012b). Gyourko and Keim (1992) emphasize the role played by the interest rate and the monetary aggregates on the dynamics of housing prices. Mishkin (2007) analyses the housing-related channels of the transmission mechanism of monetary policy, which include: (i) the direct influence of the interest rate on the expectations about future movements in house prices, the housing supply and the user cost of housing
} 
and long-lasting, quickly spreading effects have highlighted the need of a better understanding of: (i) how changes in asset prices impact on the macroeconomy (Caporale and Spagnolo, 2003); and (ii) how market volatility can be transmitted across countries during financial crises (Blenman, 2004; Caporale et al., 2006). Third, housing represents the most valuable asset in households' portfolios and provides both direct utility and collateral services (Banks et al., 2004).

In this paper, we try to assess the joint dynamics of consumption, wealth and income and housing returns. More specifically, we follow Lettau and Ludvigson (2001) and Sousa (2010a) and use the representative agent's intertemporal budget constraint to derive a relationship between the transitory deviation of consumption from the common trend with aggregate wealth and labour income, labelled as cay, and housing returns. ${ }^{4}$ In their studies, Lettau and Ludvigson (2001) and Sousa (2010a) use data for the US and the UK and provide a rationale for the link between the consumption-wealth ratio and future stock returns: when forward-looking investors expect stock returns to be higher in the future, they allow consumption to rise above its equilibrium level, thereby insulating future consumption from fluctuations in the return on financial wealth. In the same spirit, Della Corte et al. (2010) re-examine the forecasting power of cay on stock returns using a novel database for four major economies (US, UK, Japan and France) and covering one century of annual data. Interestingly, they also find considerable predictive ability for cay in the postwar period. Afonso and Sousa (2011) use data for a set of OECD countries to investigate the relationship between cay and stock returns and government bond yields. They report that when bonds are seen as a component of asset wealth, investors react in the same way as for stocks. By contrast, if the increase in government bond yields is perceived as signalling a future rise in taxes, they will temporarily reduce their consumption. Using data for the same countries, Sousa (2012a) analyses the predictive ability of the ratio of asset wealth to labour income and shows that when the wealth-to-income ratio - which captures the investor's exposure to labour income risk - falls, investors demand a higher stock risk premium. A similar link can be found for government bond yields when agents behave in a non-Ricardian manner or

capital; and (ii) the indirect impact on the real economy via balance sheet and credit-channel effects on consumer spending and housing demand and standard wealth effects from house prices. Chang et al (2011) uncover a regime-switch in the relationship between the monetary policy, the term spread and the housing market return since the mid-1970s. Chang et al. (2012, 2013) also find such regime-switching structure in some Asian countries.

${ }^{4}$ Leung and Chen (2010) develop a simple overlapping generations model with constant fundamentals and show that the stock price displays volatility and negative autocorrelation even without changes in dividend. They also find that the aggregate consumption-wealth ratio predicts asset returns. 
see government bonds as complements for stocks. By contrast, when investors display a Ricardian behaviour or perceive stocks and government bonds as good substitutes, then a fall in the wealth-to-income ratio is associated with a fall in future bond yields.

Thus, while the literature on wealth effects finds that an increase in asset wealth leads to higher consumption, the empirical finance literature provides a new perspective: by reflecting the expectations that agents have about future returns, an increase in consumption (in terms of the consumption to wealth ratio) leads to higher financial wealth (i.e. higher stock returns).

In the current paper, we argue that such a relationship also holds with respect to the predictability of the housing risk premium, although this depends on how investors perceive the degree of substitutability or complementarity between financial and housing assets. More specifically, if they are seen as complementary, investors will increase consumption above its equilibrium level when they expect a rise in housing returns. In this case, one should find a positive coefficient on cay in the forecasting regressions for future housing returns. In other words, because housing and financial assets are complements, the sign of this coefficient is consistent with the one found by Lettau and Ludvigson (2001), Sousa (2010a) and Afonso and Sousa (2011) in their forecasting regressions for future stock returns. However, if housing and financial assets are treated as substitutes, consumption will fall below its equilibrium level when housing returns are expected to rise. As a result, the coefficient associated with cay in the forecasting regressions for future housing returns should be negative. In this context, Caporale and Sousa (2011) also validate empirically the predictive power of cay for both equity and housing risk premia in a set of emerging countries. From a theoretical reasoning, the current work is also close to that of Rocha Armada and Sousa (2012) who link the wealth-to-income income to future real housing returns and interpret the empirical evidence in terms of complementarity/substitution between financial and housing assets.

\section{Theoretical Framework}

\subsection{The Intertemporal Budget Constraint}

Let us assume a representative consumer whose intertemporal budget constraint can be represented by

$$
W_{t+1}=\left(1+R_{w, t+1}\right)\left(W_{t}-C_{t}\right),
$$


where $W_{t}$ expresses aggregate wealth, $C_{t}$ corresponds to private consumption, and $R_{w, t+1}$ denotes the return on aggregate wealth between period $t$ and $t+1$.

Under the assumption that the consumption-aggregate wealth ratio is stationary and that $\lim _{i \rightarrow \infty} \rho_{w}{ }^{i}\left(c_{t+i}-w_{t+i}\right)=0$, Campbell and Mankiw (1989) use the following Taylor expansion approximation of equation (1)

$$
c_{t}-w_{t}=\sum_{i=1}^{\infty} \rho_{w}^{i} r_{w, t+i}-\sum_{i=1}^{\infty} \rho_{w}^{i} \Delta c_{t+i}+k_{w},
$$

where $c \equiv \log C, w \equiv \log W$, and $k_{w}$ is a constant.

Similarly, returns on wealth can be disaggregated into returns on asset wealth, $R_{a, t+1}$, and returns on human wealth, $R_{h, t+1}$, i.e.

$$
R_{w, t+1}=\omega_{t} R_{a, t+1}+\left(1-\omega_{t}\right) R_{h, t+1},
$$

where $\omega_{\mathrm{t}}$ is a time varying coefficient and, following Campbell (1996), we can approximate equation (3) as

$$
r_{w, t}=\omega_{t} r_{a, t}+\left(1-\omega_{t}\right) r_{h, t}+k_{r}
$$

where lowercase letters denote log returns and $k_{r}$ is a constant.

In line with Lettau and Ludvigson (2001) and Sousa (2010a, 2011), human wealth can be proxied by labour income, $y_{t}$ (i.e., $h_{t}=y_{t}+k_{h}$, where $k_{h}$ is a constant), thus, the log aggregate wealth can be approximated as

$$
w_{t}=\omega a_{t}+(1-\omega) h_{t}+k_{a} \approx \omega a_{t}+(1-\omega) y_{t}+k_{y},
$$

where $a_{t}$ is the $\log$ asset wealth, $h_{t}$ is the log human wealth, $\omega$ is the mean of $\omega_{\mathrm{t}}$, and $k_{a}$ and $k_{y}=(1-\omega) k_{h}+k_{a}$ are constants.

Using equation (4) and (5) to substitute in (2), one obtains

$$
c_{t}-\omega a_{t}-(1-\omega) y_{t}=\sum_{i=1}^{\infty} \rho_{w}^{i} r_{a, t+i}-\sum_{i=1}^{\infty} \rho_{w}^{i} \Delta c_{t+i}+\eta_{t}+k,
$$

where $\eta_{t} \equiv(1-\omega) z_{t}$ is a stationary component, and $k$ is a constant. By taking the time $t$ conditional expectation of both sides of equation (6), one obtains

$$
\underbrace{c_{t}-\omega a_{t}-(1-\omega) y_{t}}_{\text {cay }_{t}}=E_{t} \sum_{i=1}^{\infty} \rho_{w}^{i} r_{a, t+i}-E_{t} \sum_{i=1}^{\infty} \rho_{w}^{i} \Delta c_{t+i}+\eta_{t}+k .
$$

Therefore, agents will increase consumption if they expect higher future stock returns. This result can be found in Lettau and Ludvigson (2001) and Sousa (2010a) in the context of stock return predictability, and also in Afonso and Sousa (2011) when forecasting future government bond yields. 
In the current paper, we argue that the same holds for housing returns, i.e. investors typically increase their consumption when they predict that future returns on housing assets are likely to rise and financial and housing assets are seen as complementary. On the contrary, if investors forecast housing returns to be higher in the future and financial and housing assets are treated as substitutes (implying that returns on financial assets are expected to fall), they will reduce their consumption. The crucial issue is the degree of separability between financial and housing assets: when they are separable, financial and housing assets are substitutes, and transitory movements in agents' asset wealth reflecting time variation in expected returns can be smoothed out; if instead they are non-separable, financial and housing assets are complements, and adjustments in response to exogenous shocks cannot be made. Consequently, the sign of the coefficients on cay in the forecasting regressions for stock and housing returns contains very useful information.

\subsection{An Utility-Based Approach}

\subsubsection{Housing and Financial Assets’ Complementarity}

Consider the case where the representative investor has Leontief preferences visà-vis housing and financial assets, i.e.

$$
U\left(f a_{t}, h a_{t}\right)=\min \left\{f a_{t}, h a_{t}\right\},
$$

$U(\cdot)$ denotes the utility function, fa corresponds to financial assets and ha represents housing assets.

It is well known that the Marshallian demand functions for financial assets $\left(f a_{t}^{d}\right)$ and housing assets $\left(h a_{t}^{d}\right)$ in this framework can be expressed as:

$$
f a_{t}^{d}=h a_{t}^{d}=\frac{y_{t}}{p_{f a}+p_{h a}},
$$

where $y_{t}$ is the investor's income, $p_{f a}$ is the price of financial assets and $p_{h a}$ is the price of housing assets. Therefore, an increase in the price of financial assets, $p_{f a}$, leads to a fall in the demand of both financial and housing assets. Moreover, as the increase in asset prices typically signals lower returns in the future (Cochrane, 2011), when the price of financial assets or the price of housing assets rises, both expected future financial returns, $E_{t} r_{f, t+H}$, and expected future housing returns, $E_{t} r_{h, t+H}$, fall, i.e. asset returns co-move in the same direction. Consequently, cay would predict a fall in both future returns on financial assets and future returns on housing assets. 


\subsubsection{Housing and Financial Assets’ Substitution}

Consider the alternative case of a representative investor with a linear utility function over housing and financial assets, i.e.

$$
U\left(f a_{t}, h a_{t}\right)=f a_{t}+h a_{t} .
$$

In this setup, Marshallian demand functions for financial assets $\left(f a_{t}^{d}\right)$ and housing assets $\left(h a_{t}^{d}\right)$ can be represented as:

and

$$
\begin{aligned}
& f a_{t}^{d}=\left\{\begin{array}{l}
\frac{y_{t}}{p_{f a}}, \text { if } p_{f a}<p_{h a} \\
\text { any number between } 0 \text { and } \frac{y_{t}}{p_{f a}} \text { if } p_{f a}=p_{h a}, \\
0, \text { if } p_{f a}>p_{h a}
\end{array}\right. \\
& h a_{t}^{d}=\left\{\begin{array}{l}
0, \text { if } p_{f a}<p_{h a} \\
\text { any number between } 0 \text { and } \frac{y_{t}}{p_{h a}} \text { if } p_{f a}=p_{h a}, \\
\frac{y_{t}}{p_{h a}}, \text { if } p_{f a}>p_{h a}
\end{array}\right.
\end{aligned}
$$

Therefore, an increase in the price of financial assets, $p_{f a}$, leads to a fall in the demand of both financial assets and a rise in the demand of housing assets. Moreover, as the increase in the price of an asset typically leads to the expectation of lower returns in the future, when the price of financial assets rises, expected future financial returns, $E_{t} r_{f, t+H}$, fall, so investors increase their exposure to housing assets (as expected future housing returns, $E_{t} r_{h, t+H}$, increase). In this case, cay would predict a fall in future returns on financial assets and a rise in future returns on housing assets. Alternatively, when the price of housing assets rises, expected future housing returns, $E_{t} r_{h, t+H}$, fall, and investors increase their exposure to financial assets (as expected future financial returns, $E_{t} r_{f, t+H}$, increase). In this scenario, cay would predict a fall in future returns on housing assets and a rise in future returns on financial assets. Put differently, future returns on financial assets and future returns on housing assets move in different directions.

\subsection{Further Theoretical Discussion}

In this Section, we provide an overview of the relationship between our theoretical framework and others embedded in the macro-finance literature. 
The theoretical foundation of the wealth effects on consumption goes back to the work of Ando and Modigliani (1963), who rely on the simple formulation of the lifecycle model. Thus, the authors focus on aggregate measure of wealth and make no distinction between financial wealth and housing wealth. Then, they investigate how changes in aggregate wealth translate into changes in private consumption.

Following a similar framework, Case et al. (2005) argue that one cannot use the marginal propensity to consume out of all wealth to extrapolate the wealth effect for the stock market and the wealth effect for the real estate market, as consumption is affected in a different manner by the form in which wealth is held. Therefore, the authors use various reduced-form models based on a partial-equilibrium formulation to link consumption, financial wealth, housing wealth and labour income.

Lettau and Ludvigson (2001) go one step further. They use the representative agent's intertemporal budget constraint to derive a relationship between the transitory deviation of consumption from its equilibrium relationship with aggregate wealth and labour income, and future returns on stocks. Sousa (2010a) follows the same approach, but distinguishes between financial wealth and housing wealth. In these theoretical formulations, the linkage between the consumption-wealth ratio and future stock returns does not require a specific functional form for the utility function of the representative agent, as the relationship between the relevant variables is obtained via the loglinearization of the intertemporal budget constraint.

By contrast, other authors have explored different specifications of the consumer's preferences to characterize the dynamics of stock returns. For instance, Lettau et al. (2008) use the recursive utility function formulated by Epstein and Zin (1989, 1991) and Weil (1989). The authors show that the surge in equity valuation ratios observed in the U.S. during the nineties can be described as a rational response to the sharp and prolonged fall in macroeconomic risk or aggregate volatility.

Other pieces of research also rely on utility-based frameworks, but give an explicit role for housing in the preferences of the representative agent. For example, Iacoviello (2004) develops a dynamic general equilibrium model in which households derive utility from consumption and housing. Increases in house prices relax borrowing constraints and, thus, lead to higher consumption. Chen and Leung (2007) consider a model where the household derives utility from housing services and a consumption good and which incorporates intertemporal non-separability and indivisibility of the housing stock. Collateral services for investment by constrained producers and 
residential housing demand by households are provided by real estate and shocks to the housing markets amplify the exogenous economic shocks. Ren and Yuan (2014) also formulate households' preferences as depending on a consumption good and a selfowned house. The authors design a dynamic stochastic partial equilibrium model which includes three key ingredients, namely, agent heterogeneity, collateral constraints and news shocks. The model is aimed at explaining the dynamics of U.S. residential investment and emphasizes that, in response to positive news, economic agents purchase houses more than other goods because they are face collateral constraints. Thus, the authors are able to explain why residential investment leads consumption and GDP.

While these studies are more concerned with the macroeconomic impact of the dynamics of housing markets, other authors include housing in the utility function of consumers as a way of improving our understanding of equity risk premium. In this context, Yogo (2006) and Piazzesi et al. (2007) consider utility functions where preferences are non-separable between durable and non-durable consumption and housing and non-housing consumption, respectively. Therefore, changes in the ratio between the two types of consumption captures time-variation in equity premium. Lustig and van Nieuwerburgh (2005) offer a similar framework, but allow the conditional distribution of asset prices and consumption growth to be shifted as a result of changes in the housing collateral ratio. Pakos (2011) highlights the nonhomotheticity in preferences due to the presence of durable goods in households' utility. Jin et al. (2012) specify an utility function where the household derives satisfaction from consumption, housing and leisure, but which also allows for shocks to the preference for housing. The authors look at the linkages between the capital market and the real estate market and show that a positive shock to real house prices reduces the external finance premium, boosts nonresidential investment and stimulates real GDP. While the paper focuses on the macroeconomic role played by the housing market and the importance of housing as generating wealth effects and providing collateral services, the authors show that the fluctuations in real estate prices account for a large share of the volatility that we observe in asset returns.

In the current paper, we marry two model-based approaches: 1) the representative agent formulation by Lettau and Ludvigson (2001) and Sousa (2010a), which relies on the intertemporal budget constraint but is silent vis-a-vis the preferences of the consumer; and 2) a utility-based framework, where direct utility is retrieved from 
the financial and the housing assets held by the representative agent. The first approach allows us to establish a link between the deviation of consumption from its equilibrium relationship with aggregate wealth and labour income and future housing risk premium. The second approach provides a refined assessment of the degree of substitution/complementarity between financial and housing assets. Thus, while the first approach reveals that deviations of consumption from its common trend with asset wealth and labour income indicate changes in the expectations of investors about future housing returns, the second approach help us to identify what the sign of such relationship should be. Put it differently, Lettau and Ludvigson (2001) and Sousa (2010a) show that an increase in the consumption-wealth ratio predicts a rise in future equity risk premium. In our utility-based approach, we show that the same positive relationship can be found between cay and future housing returns when financial and housing assets are perceived as complementary or, alternatively, a negative link is expected when financial and housing assets are seen as substitutes.

Thus, although we do not explicitly include consumption in the preferences of the representative agent, such feature is implicitly assumed in the emphasis that we give to the consumption-wealth ratio. Additionally, our utility function is defined over the two types of assets, thus, making it possible to explain the cross-country differences that we uncover in the empirical analysis, in particular, regarding the coefficient associated with cay in the forecasting regressions for future housing returns.

\section{Empirical Results}

\subsection{Data}

We use quarterly data, post-1960, for 15 countries (Australia, Belgium, Canada, Denmark, Finland, France, Germany, Ireland, Italy, Japan, the Netherlands, Spain, Sweden, the UK, the US). The number of countries covered on this study is determined by the availability of quarterly data for such a long time span, in particular for asset wealth data and its financial and housing components. ${ }^{5}$

The consumption series correspond to the private consumption expenditure and the income series are the labour compensation from the Main Economic Indicators (MEI) of the Organization for Economic Co-Operation and Development (OECD) and

\footnotetext{
${ }^{5}$ The data used in the empirical analysis ranges over the following sample periods: Australia (1961:12010:2), Belgium (1961:1-2010:2), Canada (1961:1-2010:2), Denmark (1961:1-2010:1), Finland (1961:12010:2), France (1961:1-2010:2), Germany (1961:1-2009:4), Ireland (1961:1-2009:4), Italy (1961:12010:1), Japan (1961:1-2010:1), Netherlands (1961:1-2010:2), Spain (1961:1-2009:4), Sweden (1961:12010:2), UK (1961:1-2010:2) and US (1961:1-2010:2).
} 
the Datastream. For the US, we follow Lettau and Ludvigson (2001) in the construction of those series; for the UK, we follow Sousa (2010a). Wealth data come from the national central banks or the Eurostat.

We use aggregate data to construct the consumption-wealth ratio (Lettau and Ludvigson, 2001; Sousa, 2010a). Thus, we rely on national averages and do not formally account for the different distributions of consumption, wealth, and housing returns within each country. Similarly, we proxy human wealth with labour income (as in Lettau and Ludvigson (2001) and Sousa (2010a)). Therefore, we do not consider the impact of variables such as age in the estimation of human capital.

Housing returns are computed using the housing price index and the price-rent ratio provided by the Bank for International Settlements (BIS). The data differ from across countries with regard to the area covered, compilation method, priced unit, property, property vintage and seasonal adjustment. This is due to: 1) the various processes related with property' purchases and sales; and 2) the absence of specific international standards for property price statistics. Despite this, the compilation of the data follows the Handbook on Residential Property Price Indices drafted by the Eurostat under the aegis of the Inter-Secretariat Working Group on Price Statistics, which provides recommendations on best practice for compiling residential property price indices.

The annual population series is taken from the OECD's Main Economic Indicators and interpolated to quarterly frequency.

All series are deflated with the GDP deflators, expressed in logs of per capita terms (with the exception of housing returns), and seasonally adjusted using the X-12 method where necessary.

\subsection{Econometric Methodology}

Following Stock and Watson (1993) we estimate the equation below with dynamic ordinary least squares (DOLS):

$$
c_{t}=\mu+\beta_{a} a_{t}+\beta_{y} y_{t}+\sum_{i=-k}^{k} b_{a, i} \Delta a_{\mathbf{t}-\mathbf{i}}+\sum_{i=-k}^{k} b_{y, i} \Delta y_{\mathbf{t}-\mathbf{i}}+\varepsilon_{t},
$$


where the parameters $\beta_{a}$ and $\beta_{y}$ denote the long-run elasticities of consumption with respect to asset wealth and labour income respectively, $\Delta$ corresponds to the first difference operator, $\mu$ is a constant, and $\varepsilon_{t}$ is the error term. ${ }^{6}$

Table 1 reports the quarterly nominal housing returns for each country. It shows that, over the sample period considered, they were largest in Ireland (6.85\%), Spain (4.67\%), UK (4.36\%), Australia (4.08\%) and Italy (4.00\%). These figures are sizeable: they correspond to annual average nominal returns of $30.35 \%, 20.03 \%, 18.61 \%$, $17.35 \%$ and 16.99\%, respectively. Quarterly nominal housing returns are lowest in Germany (1.39\%) and Japan (1.64\%), largely reflecting a much more stable pattern for housing prices in these countries.

\section{[ INSERT TABLE 1 HERE. ]}

Table 2 reports the cointegrating vector of consumption, asset wealth, and labour income. As in Afonso and Sousa (2011), the long-run elasticity of consumption with respect to labour income is roughly twice as large as that associated with aggregate wealth.

\section{[ INSERT TABLE 2 HERE. ]}

\subsection{Forecasts for Real Housing Returns}

We first consider real housing returns (denoted by $H R_{t}$ ). Table 3 concerns the predictive ability of cay $_{t}$ at different horizons and presents a summary of the OLS regressions of the $H$-period real housing return, $H R_{t+1}+\ldots+H R_{t+H}$, on the lag of cayt.

The empirical findings show that cayt is statistically significant for a large number of countries. Its sign is generally positive and the point estimate of the coefficient is large, thus, reflecting an increase in consumption above its equibrium level when investors expect higher real housing returns. In addition, cayt predicts a significant percentage of the dynamics of future real returns (as measured by the adjusted R-square), especially at long horizons. For instance, cayt predicts 6\% (Italy), 7\% (Finland), 8\% (Denmark), 11\% (Australia), 14\% (Japan), 23\% (UK), 25\%

\footnotetext{
${ }^{6}$ As a preliminary step, we test for unit roots in consumption, aggregate wealth and labour income using the Augmented Dickey-Fuller and the Phillips-Perron tests. These show that the three variables are integrated of order one. Then, we apply the Engle-Granger test for cointegration, which confirms the existence of an equilibrium relationship between the three variables.
} 
(Belgium), 49\% (Canada) and 56\% (Spain) of the real housing return over the next eight quarters. By contrast, the model does not seem to perform well in the case of France, Germany, Ireland and the US.

The estimated sign of the coefficient of cayt $_{t}$ is positive for Australia, Belgium, Canada, Denmark, Finland, Ireland, Italy, Japan, Spain, Sweden, UK and US, and negative for France, Germany, and Netherlands. On the basis of our theoretical framework described in Section 3, this evidence suggests that, for the first set of countries, agents increase consumption above its equilibrium relationship with asset wealth and labour income when they expect housing returns to rise in the future, that is, financial and housing assets are complements. As for the second set of countries, it appears that investors see financial and housing assets as substitutes.

\section{[ INSERT TABLE 3 HERE. ]}

\subsection{Forecasts for Excess Housing Returns}

Next, we examine the forecasting power of cayt in predicting excess housing returns (denoted by $E R_{t}$ ). Table 4 provides a summary of the OLS regressions of the $H$ period excess housing return, $E R_{t+1}+\ldots+E R_{t+H}$, on the lag of cayt. It shows that cayt is a strong predictor of future excess housing returns. At the eight quarter horizon, cayt forecasts 5\% (Australia), 7\% (Italy), 9\% (UK), 10\% (France and Netherlands), 12\% (Denmark), 14\% (Finland), 24\% (Sweden), 29\% (Belgium), 35\% (Spain), 36\% (Japan) and $46 \%$ (Canada) of the excess housing risk premium in the coming eight quarters. The predictive ability of cayt is instead virtually nil in Germany, Ireland and the US.

The coefficient on cayt $_{t}$ is positive for Belgium, Canada, Denmark, Finland, Ireland, Italy, Japan, Spain, Sweden, UK and US, and negative for Australia, France, Germany, and Netherlands. As a result, in the first group of countries, financial and housing assets are best described as complementary assets, while in the second group, investors perceive them as substitutes.

[ INSERT TABLE 4 HERE. ] 


\section{Sensitivity Analysis}

\subsection{Potential Bias}

Stambaugh (1999) shows that when the regressor displays persistence, the dependent variable is not independent of the leads and lags of the error terms and the point coefficient estimates in the forecasting regressions at different horizons will be biased upwards.

Consequently, in Table 5, we report the size of the bias associated with the predictive power of cay. As can be seen, it does not represent more than $10 \%$ of the coefficient of cay, implying that the consumption-wealth ratio remains a relevant predictor of both real and excess housing returns.

\section{[ INSERT TABLE 5 HERE. ]}

\section{2. “Look-Ahead” Bias}

Another econometric issue that may arise with the forecasting regressions at hand has to do with the fact that cay is estimated using the full sample period. Thus, the forecasting regressions are based on a cointegrating vector that is fixed over the entire sample, which may lead to the so-called "look-ahead” bias (Brennan and Xia, 2005).

With this caveat in mind, we reestimate cay over the last forty quarters of the sample using only data that are available to the investor at the time of the forecast (reestimated cointegrating vector). The obvious drawback of this technique is that it can understate the forecasting power of the regressor (as we constrain the usable dataset), hence making it more difficult for cay to exhibit predictive ability even though it may represent the "true" model describing the behaviour of housing risk premium (Lettau and Ludvigson, 2001).

Tables 6 and 7 summarize the results and confirm the predictive ability of cay in the regressions for both real housing returns and excess housing returns: the statistical significance of cay remains unchanged and the adjusted R-square statistics are also similar to that of the previous regressions. For instance, at the eight quarter horizon, cay captures 35\% (Sweden), 22\% (Canada), 19\% (UK), 10\% (Australia), 9\% (Japan) and $5 \%$ (Denmark) of the variation in real housing returns. As for excess housing returns, cay tracks 20\% (Japan and Sweden), 14\% (Canada), 11\% (Spain), 10\% (Finland and UK) and 6\% (Denmark and France) of their behaviour over the following eight quarters. 
Consequently, these empirical findings suggest that the predictive power of cay is not ultimately affected by the presence of a "look-ahead" bias.

\section{[ INSERT TABLE 6 HERE. ]}

\section{[ INSERT TABLE 7 HERE. ]}

\subsection{Additional Variables}

In order to further assess the sensitivity of our findings to additional control variables, Tables 8 and 9 report the results where we include the lag of the rent yield ratio (RentYld $t_{t-1}$ ) among the set of predictors for real and excess housing returns, respectively. As Davis and Kutan (2003) highlight that inflation is a predictor of asset returns, we also consider the lag of the inflation rate (Inflation $_{t-1}$ ) as a potential explanatory variable for housing returns. Finally, we add the lag of real housing returns $\left(H R_{t-1}\right)$.

For brevity, we only present a summary of the findings for the forecasting regressions at the eight-quarter horizon for which the predictability power of cay was found to be largest.

The empirical findings corroborate the magnitude and the statistical significance of cay. In line with the work of Case and Shiller (1989), the lag of housing returns is significant, which reflects the high autocorrelation of the dependent variable. The rent yield ratio $\left(\right.$ RentYld ${ }_{\mathrm{t}}$ ) also provides a contribution to explain the dynamics of housing risk premium given that it is significant and it increases the explanatory power of the model in the vast majority of regressions.

Finally, the coefficient associated with the inflation rate ( Inflation $\left._{t-1}\right)$ is small in magnitude, but it tends to be statistically significant, especially in the forecasting regressions for real housing returns. Moreover, it is: 1) positive for Belgium, Canada, Finland, Germany and Sweden, which suggests that agents have a myopic behaviour and suffer from money illusion; and 2) negative for Italy, the UK and the US, where investors seem to use housing assets to hedge against the risk of inflation, as in Blenman (1990).

[ INSERT TABLE 8 HERE. ] 


\section{[ INSERT TABLE 9 HERE. ]}

\subsection{Does cay Forecast Consumption Growth?}

In the light of the fact that cay could capture not only the behaviour of future housing risk premium, but also expected future consumption growth, we investigate, in Table 10, the predictive ability of cay for consumption growth over different horizons.

The empirical findings do not support the existence of a relevant forecasting power of cay for future consumption growth, a result that is in line with the works of Lettau and Ludvigson (2001) and Sousa (2010a). As can be seen, cay does not emerge as a significant predictor and the performance of the model is very poor. Even for countries like Canada, Spain, Sweden and the UK, where the residuals from the contegrating relationship among consumption, asset wealth and labour income display some predictive power, the coefficient estimates associated with cay are still small. Consequently, cay appears to be a crucial proxy for future variation in housing risk premium.

\section{[ INSERT TABLE 10 HERE. ]}

\subsection{Nested Forecast Comparisons}

Inoue and Kilian (2005) emphasize that in-sample and out-of-sample tests are asymptotically equally reliable under the null of no predictability. Rapach and Wohar (2006) also critically analyse stock return predictability under the lens of in-sample and out-of-sample tests. Thus, we also carry out nested forecast comparisons, where we compare the mean-squared forecasting error from a series of one-quarter-ahead out-ofsample forecasts obtained from a model that includes cay as the only predictor, to that from two benchmark models that do not include it. These benchmark models are the autoregressive and the constant expected returns models.

The nested forecast comparisons for the equations of the real and excess housing returns using cay can be found in Table 11, and reveal that the inclusion of cay typically improves the forecasting performance of the model vis-a-vis the benchmark specifications.

[ INSERT TABLE 11 HERE. ] 


\subsection{Country Characteristics}

We now turn to the assessment of the role played by specific country characteristics in explaining the predictive ability of cay for future housing risk premium.

While this empirical exercise has already been considered with regard to stock return predictability (Rangvid et al. (2014); Jordan et al. (2014); Rocha Armada et al. (2014)), our contribution in the context of forecasting housing returns is novel.

Thus, we start by providing an overview of the panel correlation between real housing returns and a series of country characteristics, such as: (i) the risk-free rate (RF); (ii) the real GDP per capita (GDP); (iii) the real GDP growth rate (GROWTH); (iv) the leverage ratio (LEV); (v) the size of the country as proxied by the population (POP); and (vi) the inflation rate (INFL). ${ }^{7}$ Data for country characteristics are collected from Datastream.

Figures 1a-1c scatter diagrams of real housing returns at 1-quarter, 4-quarters and 8-quarters horizons and each of the country characteristics mentioned before. As can be seen, they suggest that real housing returns are negatively associated with the real GDP per capita and the real GDP growth rate - with the relationship being stronger at longer horizons - and, to some extent, the leverage ratio. Real housing returns seem to be positively correlated with inflation. By contrast, the panel framework does not uncover a clear relationship between real housing returns and the risk-free rate or the population.

[ INSERT FIGURE 1a HERE. ]

[ INSERT FIGURE 1b HERE. ]

\section{[ INSERT FIGURE 1c HERE. ]}

Next, we compute, for each country, the correlation between real housing returns at different horizons and the country characteristics previously presented. Table 12 reports the results. As expected, the risk-free rate (RF) is negatively and significantly correlated with real housing returns. This finding is observed for almost all countries,

\footnotetext{
7 For brevity, this Section focuses on real housing returns. However, the evidence based on excess housing returns is available upon request.
} 
especially, in Belgium, Denmark, Finland, France, Ireland, Netherlands and Sweden, where the correlation is particularly strong, which suggests that housing market returns are quite sensitive to changes in the interest rate in these countries.

As for the real GDP per capita (GDP), we find that it is negatively and significantly correlated with real housing returns in the case of France, Italy, Ireland, Japan, Netherlands, Spain and Sweden. Thus, a higher level of development is generally associated with lower housing market returns. A similar result is found with regard to the correlation tests between real housing market returns and the real GDP growth rate (GROWTH) in France, Italy, Ireland, Japan, Netherlands, Spain and Sweden.

In what concerns the leverage ratio (LEV), it is negatively and significantly correlated with real housing returns in the case of Finland, France, Italy, Japan and Spain. Therefore, a higher leverage ratio (as proxied by a higher ratio of domestic credit to GDP) is associated with lower housing returns.

Interestingly, the size of the country (which is proxied by population) appears to be negatively and significantly correlated with real housing returns in Italy and Japan, and positively and significantly correlated in the case of Netherlands and Sweden. Consequently, this country characteristic does not seem to justify the cross-country heterogeneity that we observe in the predictive ability of the consumption-wealth ratio.

Finally, we can see that inflation typically displays a negative and significant correlation with real housing returns in Australia, France, Netherlands, UK and US, and a positive and significant relationship in the case of Belgium, Finland, Italy, Japan, Spain and Sweden. As a result, while for the former set of countries a myopic behaviour seems to be in place, for the latter countries investors seem to hedge against the inflation risk by increasing their exposure to real estate.

Summing up, we find a negative relationship between real housing returns and the risk-free rate, the real GDP per capita and the real GDP growth rate for a large number of countries. By contrast, the sign of the correlation between real housing returns and inflation varies across countries, and real housing returns do not seem to be correlated with the size of the country (as proxied by population).

\section{[ INSERT TABLE 12 HERE. ]}

With the aim of improving our understanding of the linkages between housing return predictability and country characteristics, we estimate pooled regressions where 
the dependent variable is the adjusted R-square of the individual forecasting regressions reported in Table 3 and the explanatory variables are the country characteristics described above (where each variable enters individually at time). This empirical exercise follows the works of Rangvid et al. (2014), Jordan et al. (2014) and Rocha Armada et al. (2014) and should provide further analysis on the differences in housing return predictability that we previously uncovered in the forecasting regressions estimated at the country-level.

A summary of the findings is reported in Table 13. It can be seen that a higher risk-free rate is associated with larger housing return predictability. This explains the low adjusted R-square statistics associated with the forecasting regressions of Finland, France, Germany and the US.

Interestingly, when the real GDP per capita and the real GDP growth rate increase, the explanatory power of our model decreases. The negative relationship between real GDP per capita and housing return predictability is again in line with the weak performance of countries like France, Germany and the US. As for the negative link between the real GDP growth rate and the predictability of real housing returns, it corroborates the idea that the dynamics of housing market is easier to forecast when real economic activity slows down: when a key driver of the housing market such as income contracts, real estate activity falls too, thus, making negative housing returns more predictable. By contrast, a rebound in output may be followed or not by a recovery of the housing market. Consequently, when output surges, the direction that the housing market takes remains unclear and so housing returns are more difficult to predict.

We also find that a higher leverage ratio is typically linked with stronger housing return predictability. This explains strong predictive power that cay exhibits in the forecasting regressions for Japan, Spain, Sweden and the UK. In fact, these countries rank among those with the largest domestic credit to private sector in percentage of GDP.

A similar result applies to inflation, as the R-square of the forecasting regressions is larger when inflation is higher. Indeed, when compared to other countries, the predictive ability of cay is particularly strong in countries like Australia, Canada, Spain, Sweden and the UK, which display relatively high mean inflation rates over the sample period.

Finally, differences in the size of the country (as proxied by population) do not seem to explain the performance of the forecasting regressions. For this reason, the poor 
predictive ability of the consumption-wealth ratio is observed both for small countries like Finland and Ireland and large countries such as Germany and the US.

All in all, the cross-country heterogeneity that we find in the predictive ability of the consumption-wealth ratio in capturing the future dynamics of real housing returns seems to be attributed to differences in the macroeconomic environment (as captured by the real GDP per capita, the real GDP growth rate and the inflation rate), money market conditions (as reproduced by the risk-free rate) and the access to credit (as proxied by the leverage ratio). By contrast, those differences appear to accrue less to the size of the country.

\section{[ INSERT TABLE 13 HERE. ]}

\section{Conclusions}

In this paper, we focus, in the context of a representative consumer model, on the equilibrium relationship between the trend deviations among consumption, aggregate wealth and labour income (summarised by the variable cay) and housing risk premium.

We argue that cay provides information not only about agent's expectations of future stock returns (as Lettau and Ludvigson (2001) and Sousa (2010a) show), but also of future housing returns. As a result, when financial and housing assets are seen as complements and investors expect an increase in housing returns, they allow consumption to rise above its equilibrium level. However, they let it fall below its equilibrium relationship with wealth and labour income when financial and housing assets are seen as substitutes.

Using quarterly-frequency data for 15 OECD countries, we find that cay forecasts more than $10 \%$ of the variation in real housing returns in countries such as Australia, Japan, the UK, Belgium, Canada and Spain at the eight-quarter horizon.

We also show that in the forecasting regressions the sign of the coefficient on cay is positive for Belgium, Canada, Denmark, Finland, Ireland, Italy, Japan, Spain, Sweden, the UK and the US, which supports the idea that financial and housing assets are complements in these countries. In contrast, it is negative for France, Germany and the Netherlands, corroborating the existence of an important degree of substitution between financial and housing assets. 
In addition to providing valuable information on the forecasting properties of the consumption-wealth ratio for housing returns, this paper opens new avenues for further work. For instance, the empirical evidence suggests that cay explains a small fraction of the variation in future real returns in some countries (such as Italy or Finland) and a large fraction in other countries (namely, Canada or Spain).

Thus, we analyse why the predictive ability of the consumption-wealth ratio varies substantially across countries. Our exploratory assessment reveals that an important fraction of such cross-country heterogeneity can be attributed to differences in macroeconomic factors, money market conditions and credit access easiness, but not in the country size. We plan to investigate further this issue and the sources behind substitutability or complementarity between financial and housing assets in future research.

\section{References}

Afonso, A., Sousa, R.M., 2011. Consumption, wealth, stock and government bond returns: international evidence. The Manchester School, 79(6), 1294-1232.

Agnello, L., Schuknecht, L., 2011. Booms and busts in housing markets: determinants and implications. Journal of Housing Economics, 20(3), 171-190.

Agnello, L., Castro, V., Sousa, R.M., 2012. How does fiscal policy react to wealth composition and asset prices? Journal of Macroeconomics, 34(3), 874-890.

Agnello, L., Castro, V., Sousa, R.M., 2013. What determines the likelihood of a fiscal consolidation program? Journal of International Money and Finance, 37, 113-134.

Ando, A., Modigliani, F., 1963. The 'life cycle' hypothesis of saving: aggregate implications and tests. American Economic Review, 53, 55-84.

Aoki, K., Proudman, J., Vlieghe, J., 2001. House prices, consumption and monetary policy: a financial accelerator approach. Journal of Financial Intermediation, 13, 414-435.

Attanasio, O.P., Blow, L., Hamilton, R., Leicester, A., 2009. Booms and busts: Consumption, house prices and expectations. Economica, 76, 20-50.

Banks, J., Blundell, R., Smith, J., 2004. Wealth portfolios in the United Kingdom and the United States. Perspectives on the Economics of Aging. National Bureau of Economic Research.

Benjamin, J., Chinloy, P., Jud, G., 2004. Real estate versus financial wealth in consumption. Journal of Real Estate Finance and Economics, 29, 341-354. 
Blenman, L.P., 1990. Price forecasts and interest rate forecasts: An extension of Levy’s hypothesis. The Journal of Futures Markets, 10(6), 605-610.

Blenman, L.P., 1991. A model of covered interest arbitrage under market segmentation. Journal of Money, Credit and Banking, 23(4), 706-717.

Blenman, L.P., 2004. Financial crisis: Contagion effects, risk premiums and returns in equity and currency markets. International Review of Financial Analysis, 13, 367380.

Bostic, R., Gabriel, S., Painter, G., 2009. Housing wealth, financial wealth, and consumption: New evidence from micro data. Regional Science and Urban Economics, 39, 79-89.

Brennan, M., Xia, Y., 2005. tay's as good as cay. Finance Research Letters, 2, 1-14.

Campbell, J. Y., 1996. Understanding risk and return. Journal of Political Economy, 104, 298-345.

Campbell, J., Cocco, J., 2007. How do house prices affect consumption? Evidence from micro data. Journal of Monetary Economics, 54, 591-621.

Campbell, J.Y., Mankiw, N., 1989. Consumption, income, and interest rates: Reinterpreting the time series evidence. National Bureau of Economic Research Macroeconomics Annual, 5. In: Blanchard, O., Fischer, S. (Eds.), MIT Press, Cambridge, Massachussets, 185-216.

Campbell, J.Y., Shiller, R.J., 1988. The dividend-price ratio and expectations of future dividends and discount factors. Review of Financial Studies, 1, 195-228.

Caporale, G.M., Kontonikas, A., 2009. The Euro and inflation uncertainty in the European Monetary Union. Journal of International Money and Finance, 28(6), 954971.

Caporale, G.M., Pittis, N., Spagnolo, N., 2006. Volatility transmission and financial crises. Journal of Economics and Finance, 30(3), 376-390.

Caporale, G.M., Spagnolo, N., 2003. Asset prices and output growth volatility: the effects of financial crises. Economics Letters, 79(1), 69-74.

Case, K.E., Quigley, J.M., Shiller, R.J., 2005. Comparing wealth effects: the stock market versus the housing market. Advances in Microeconomics, 5(1), 1-32.

Case, K.E., Quigley, J.M., Shiller, R.J., 2011. Wealth effects revisited: 1978-2009. Yale University, Cowles Foundation Discussion Paper No. 1784.

Case, K.E., Shiller, R.J., 1989. The efficiency of the market for single-family homes. American Economic Review, 79, 125-137. 
Castro, V., 2011. Can central banks' monetary policy be described by a linear (augmented) Taylor rule or by a nonlinear rule? Journal of Financial Stability, 7(4), 228-246.

Chang, K.-L., Chen, N.-K., Leung, C.K.Y., 2011. Monetary policy, term structure and asset return: Comparing REIT, housing and stock. Journal of Real Estate Finance and Economics, 43(1), 221-257.

Chang, K.-L., Chen, N.-K., Leung, C.K.Y., 2012. The dynamics of housing returns in Singapore: How important are the international transmission mechanisms? Regional Science and Urban Economics, 42(3), 516-530.

Chang, K.-L., Chen, N.-K., Leung, C.K.Y., 2013. In the shadow of the United States: The international transmission effect of asset returns. Pacific Economic Review, 18(1), 1-40.

Chen, N.-K., Leung, C.K.Y., 2007. Asset price spillover, collateral and crises: With an application to property market policy. Journal of Real Estate Finance and Economics, 37(4), 351-385.

Cho, S., 2011. Housing wealth effect on consumption: Evidence from household level data. Economics Letters, 113, 192-194.

Cochrane, J. H., 2011. Presidential address: Discount rates. Journal of Finance, 66(4), 1047-1108.

Constantinides, G., 1990. Habit-formation: A resolution of the equity premium puzzle. Journal of Political Economy, 98, 519-543.

Cover, J. P., Mallick, S. K., 2012. Identifying sources of macroeconomic and exchange rate fluctuations in the UK. Journal of International Money and Finance, 31(6), 1627-1648.

Davis, N., Kutan, A. M., 2003. Inflation and output as predictors of stock returns and volatility: International evidence. Applied Financial Economics, 13, 693-700.

Della Corte, P., Sarno, L., Valente, G., 2010. A century of equity premium predictability and consumption-wealth ratio: An international perspective. Journal of Empirical Finance, 17(3), 313-331.

Epstein, L., Zin, S., 1989. Substitution risk aversion and the temporal behavior of consumption and asset returns: A theoretical framework. Econometrica, 57, 937-968.

Epstein, L., Zin, S., 1991. Substitution, risk aversion, and the temporal behavior of consumption and asset returns: An empirical investigation. Journal of Political Economy, 99, 555-576. 
Fama, E. F., French, K. R., 1988. Permanent and temporary components of stock prices. Journal of Political Economy, 96, 246-273.

Fama, E. F., French, K. R., 1996. Multifactor explanations of asset pricing anomalies. Journal of Financial Economics, 51(1), 55-84.

Granville, B., Mallick, S. K., 2009. Monetary and financial stability in the euro area: Pro-cyclicality versus trade-off. Journal of International Financial Markets, Institutions and Money, 19, 662-674.

Gyourko, J., Keim, D.B., 1992. What does the stock market tell us about real estate returns? Real Estate Economics, 20(3), 457-485.

Hwang, M., Quigley, J., 2006. Economic fundamentals in local housing markets: Evidence from US metropolitan regions. Journal of Regional Science, 46(3), 425453.

Iacoviello, M., 2004. Consumption, house prices, and collateral constraints: a structural econometric analysis. Journal of Housing Economics, 13, 304-320.

Inoue, A., Kilian, L.,2005. In-sample and out-of-sample tests of predictability: Which one should we use? Econometric Reviews, 23(4), 371-402.

Jin, Y., Leung, C.K.Y., Zeng, Z., 2012. Real estate, the external finance premium and business investment: A quantitative dynamic general equilibrium analysis. Real Estate Economics, 40(1), 167-195.

Jordan, S.J., Vivian, A., Wohar, M.E., 2014. Sticky prices or economically-linked economies: The case of forecasting the Chinese stock market. Journal of International Money and Finance, 41, 95-109.

Kallberg, J. G., Liu, C.H., Pasquariello, P., 2002. Regime shifts in Asian equity and real estate markets. Real Estate Economics, 30(2), 263-291.

Kallberg, J. G., Liu, C.H., Pasquariello, P., 2014. On the price comovement of U.S. residential real estate markets. Real Estate Economics, 42(1), 71-108.

King, M., 1990. Discussion. Economic Policy, 11, 383-387.

Lettau, M., Ludvigson, S., 2001. Consumption, aggregate wealth, and expected stock returns. Journal of Finance, 41(3), 815-849.

Lettau, M., Ludvigson, S., 2004. Understanding trend and cycle in asset values: Reevaluating the wealth effect on consumption. American Economic Review, 94, 276-299. 
Lettau, M., Ludvigson, S., Wachter, J.A., 2008. The declining equity premium: What role does macroeconomic risk play? The Review of Financial Studies, 21(4), 16531687.

Leung, C.K.Y., 2004. Macroeconomics and housing: a review of the literature. Journal of Housing Economics, 13, 249-267.

Leung, C.K.Y., 2007. Equilibrium correlations of asset price and return. Journal of Real Estate Finance and Economics, 34(2), 233-256.

Leung, C.K.Y., Chen, N.-K., 2010. Stock price volatility, negative autocorrelation and the consumption-wealth ratio: The case of constant fundamentals. Pacific Economic Review, 15(2), 224-245.

Leung, C.K.Y., Leong, Y., Wong, S., 2006. Housing price dispersion: An empirical investigation. Journal of Real Estate Finance and Economics, 32(3), 357-385.

Ludvigson, S., Ng, S., 2009. Macro factors in bond risk premia. Review of Financial Studies, 22, 5027-5067.

Ludvigson, S., Steindel, C., 1999. How important is the stock market effect on consumption? Federal Reserve Bank of New York Economic Policy Review, July, 2951.

Lustig, H., van Nieuwerburgh, S., 2005. Housing collateral, consumption insurance, and risk premia: an empirical perspective. Journal of Finance, 60, 1167-1219.

Mallick, S. K., Mohsin, M., 2007. Monetary policy in high inflation open economies: Evidence from Israel and Turkey. International Journal of Finance and Economics, 12(4), 405-415.

Mallick, S. K., Mohsin, M., 2010. On the real effects of inflation in open economies: theory and empirics. Empirical Economics, 39(3), 643-673.

Mishkin, F.S., 2007. Housing and the monetary transmission mechanism. National Bureau of Economic Research, NBER Working Paper No. 13518.

Muellbauer, J., Murphy, A., 1990. Is the UK balance of payments sustainable? Economic Policy, 11, 345-383.

Newey, W., West, K., 1987. A simple positive semi-definite, heterokedasticity, and autocorrelation consistent covariance matrix. Econometrica, 55(3), 703-708.

Quijano, M., 2012. A refined consumption-wealth ratio and its role on time-varying consumption risk. Economics Letters, 115(1), 88-90.

Pagano, M., 1990. Discussion. Economic Policy, 11, 387-390. 
Pakos, M., 2011. Estimating intertemporal and intratemporal substitutions when both income and substitution effects are present: the role of durable goods. Journal of Business and Economic Statistics, 29(3), 439-454.

Piazzesi, M., Schneider, M., Tuzel, S., 2007. Housing, consumption and asset pricing. Journal of Financial Economics, 83, 531-569.

Rafiq, M. S., Mallick, S. K., 2008. The effect of monetary policy on output in EMU3: a sign restriction approach. Journal of Macroeconomics, 30, 1756-1791.

Rangvid, J., Schmeling, M., Schrimpf, A., 2014. Dividend predictability around theworld. Journal of Financial and Quantitative Analysis, forthcoming.

Rapach, D.E., Wohar, M.E., 2006. In-sample and out-of-sample tests of stock return predictability in the context of data mining. Journal of Empirical Finance, 13, 231247.

Rapach, D.E., Wohar, M.E., 2009. Multi-period portfolio choice and the intertemporal hedging demands for stocks and bonds: International evidence. Journal of International Money and Finance, 28(3), 427-453.

Rapach, D.E., Wohar, M.E., Rangvid, J., 2005. Macro variables and international stock return predictability. International Journal of Forecasting, 21(1), 137-166.

Ren, Y., Yuan, Y., 2014. Why the housing sector leads the whole economy: the importance of collateral constraints and news shocks. Journal of Real Estate Finance and Economics, 48(2), 323-341.

Ren, Y., Yuan, Y., Zhang, Y., 2014. Human capital, household capital and asset returns. Journal of Banking and Finance, 42, 11-22.

Rocha Armada, M.J., Sousa, R.M., 2012. Can the wealth-to-income ratio be a useful predictor in Alternative Finance? Evidence from the housing risk premium. In: Barnett, W.A., Jawadi, F., Eds. Recent Developments in Alternative Finance: Empirical Assessments and Economic Implications, International Symposia in Economic Theory and Econometrics, 22, 67-79, Emerald Group Publishing, Bingley, UK.

Rocha Armada, M.J., Sousa, R.M., Wohar, M.E., 2014. Consumption growth, preference for smoothing, changes in expectations and risk premium. Quarterly Review of Economics and Finance, forthcoming.

Sousa, R. M., 2010a. Consumption, (dis)aggregate wealth, and asset returns. Journal of Empirical Finance, 17(4), 606-622. 
Sousa, R.M., 2010b. Collateralizable wealth, asset returns and systemic risk: international evidence. In: Barnett, W.A., Jawadi, F., Eds. Nonlinear Modeling of Economic and Financial Time-Series, International Symposia in Economic Theory and Econometrics, 20, 1-27, Emerald Group Publishing, London, UK.

Sousa, R. M., 2010c. Housing wealth, financial wealth, money demand and policy rule: Evidence from the Euro Area. North American Journal of Economics and Finance, 21(1), 88-105.

Sousa, R.M., 2011. Building empirical proxies that capture time-variation in expected returns using a VAR approach. Applied Financial Economics, 21(3), 147-163.

Sousa, R. M., 2012a. Linking wealth and labour income with stock returns and government bond yields. European Journal of Finance, forthcoming.

Sousa, R.M., 2012b. What is the impact of wealth shocks on asset allocation? Quantitative Finance, forthcoming.

Stambaugh, R. F., 1999. Predictive regressions. Journal of Financial Economics, 54(3), $375-421$.

Stock, J., Watson, M., 1993. A simple estimator of cointegrating vectors in higher order integrated systems. Econometrica, 61(4), 783-820.

Thornton, D. L., Valente, G., 2009. Revisiting the predictability of bond risk premia. Federal Reserve Bank of St. Louis, Working Paper No. 009A.

Thornton, D. L., Valente, G., 2012. Out-of-sample predictions of bond excess returns and forward rates: An asset allocation perspective. Review of Financial Studies, 25(10), 3141-3168.

Weil, P., 1989. The equity premium puzzle and the risk-free rate puzzle. Journal of Monetary Economics, 24(3), 401-421.

Yogo, M., 2006. A consumption-based explanation of expected stock returns. Journal of Finance, 61(2), 539-580. 


\section{List of Tables}

Table 1 - Nominal housing returns.

\begin{tabular}{lcclcc} 
& Mean & St. Dev. & Country & Mean & St. Dev. \\
\hline Australia & $4.08 \%$ & 0.0227 & Italy & $4.00 \%$ & 0.0463 \\
Belgium & $2.72 \%$ & 0.0157 & Japan & $1.64 \%$ & 0.0218 \\
Canada & $3.39 \%$ & 0.0274 & Netherlands & $3.30 \%$ & 0.0277 \\
Denmark & $2.91 \%$ & 0.0263 & Spain & $4.67 \%$ & 0.0266 \\
Finland & $3.08 \%$ & 0.0306 & Sweden & $2.60 \%$ & 0.0203 \\
France & $3.32 \%$ & 0.0153 & UK & $4.36 \%$ & 0.0268 \\
Germany & $1.39 \%$ & 0.0094 & US & $2.80 \%$ & 0.0090 \\
Ireland & $6.85 \%$ & 0.0383 & & & \\
\hline
\end{tabular}

Table 2 - The cointegrating vector of consumption, aggregate wealth, and labour income.

\begin{tabular}{|c|c|c|c|}
\hline Australia & $\begin{array}{c}\text { cay }_{\mathrm{t}}:=\mathrm{c}_{\mathrm{t}-}-0.35^{* * *} \mathrm{a}_{\mathrm{t}}-0.54^{* * *} \mathrm{y}_{\mathrm{t}} \\
(13.39)\end{array}$ & Italy & $\begin{array}{c}\text { cayt }_{\mathrm{t}}:=\mathrm{c}_{\mathrm{t}}+0.02 \mathrm{a}_{\mathrm{t}}-1.49 * * * \mathrm{y}_{\mathrm{t}} \\
(-0.20)\end{array}$ \\
\hline Belgium & cayt $_{\mathrm{t}}:=\mathrm{c}_{\mathrm{t}}-\underset{(8.02)}{0.16^{* * *} \mathrm{a}_{\mathrm{t}}-0.56^{* * *}} \mathrm{y}_{\mathrm{t}}$ & Japan & cayt $_{\mathrm{t}}:=\mathrm{c}_{\mathrm{t}}-0.08^{* * *} \mathrm{a}_{\mathrm{t}}-0.89^{* * *} \mathrm{y}_{\mathrm{t}}$ \\
\hline Canada & cayt $_{\mathrm{t}}:=\mathrm{c}_{\mathrm{t}}-0.36^{* * *} \mathrm{a}_{\mathrm{t}}-0.56^{* * *} \mathrm{y}_{\mathrm{t}}$ & Netherlands & $\begin{array}{c}\text { cayt }_{\mathrm{t}}:=\mathrm{c}_{\mathrm{t}}-0.17^{* * * *} \mathrm{a}_{\mathrm{t}}-0.53^{* * *} \mathrm{y}_{\mathrm{t}} \\
(12.92)\end{array}$ \\
\hline Denmark & cay $_{\mathrm{t}}:=\mathrm{c}_{\mathrm{t}}-\underset{(6.12)}{0.09 * * *} \mathrm{a}_{\mathrm{t}}-0.65^{* * *} \mathrm{y}_{\mathrm{t}}$ & Spain & $\begin{array}{c}\text { cayt }_{t}:=c_{t}-0.06^{*} a_{t}-0.76^{* * *} y_{t} \\
(1.67) \quad(16.10)\end{array}$ \\
\hline Finland & $\operatorname{cay}_{\mathrm{t}}:=\mathrm{c}_{\mathrm{t}}-0.38 * * * \mathrm{a}_{\mathrm{t}}-0.13 \mathrm{y}_{\mathrm{t}}$ & Sweden & $\begin{aligned} \text { cay }_{\mathrm{t}}:=\mathrm{c}_{\mathrm{t}}+ & 0.13^{* *} \mathrm{a}_{\mathrm{t}}-1.12^{* * *} \mathrm{y}_{\mathrm{t}} \\
(-2.45) & (9.06)\end{aligned}$ \\
\hline France & cayt $_{\mathrm{t}}:=\mathrm{c}_{\mathrm{t}}-0.25^{* * *} \mathrm{a}_{\mathrm{t}}-0.55^{* * *} \mathrm{y}_{\mathrm{t}}$ & UK & $\begin{array}{c}\text { cayt }_{\mathrm{t}}:=\mathrm{c}_{\mathrm{t}}-0.32^{* * *} \mathrm{a}_{\mathrm{t}}-0.66^{* * *} \mathrm{y}_{\mathrm{t}} \\
(13.84)\end{array}$ \\
\hline Germany & $\operatorname{cay}_{t}:=c_{t}-0.13^{*} a_{t}-1.16^{* * *} y_{t}$ & US & $\begin{array}{c}\text { cayt }_{\mathrm{t}}:=\mathrm{c}_{\mathrm{t}}-0.28 * * * \\
(17.14)\end{array}$ \\
\hline Ireland & 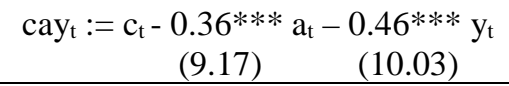 & & \\
\hline
\end{tabular}


Table 3 - Forecasting real housing returns using cay.

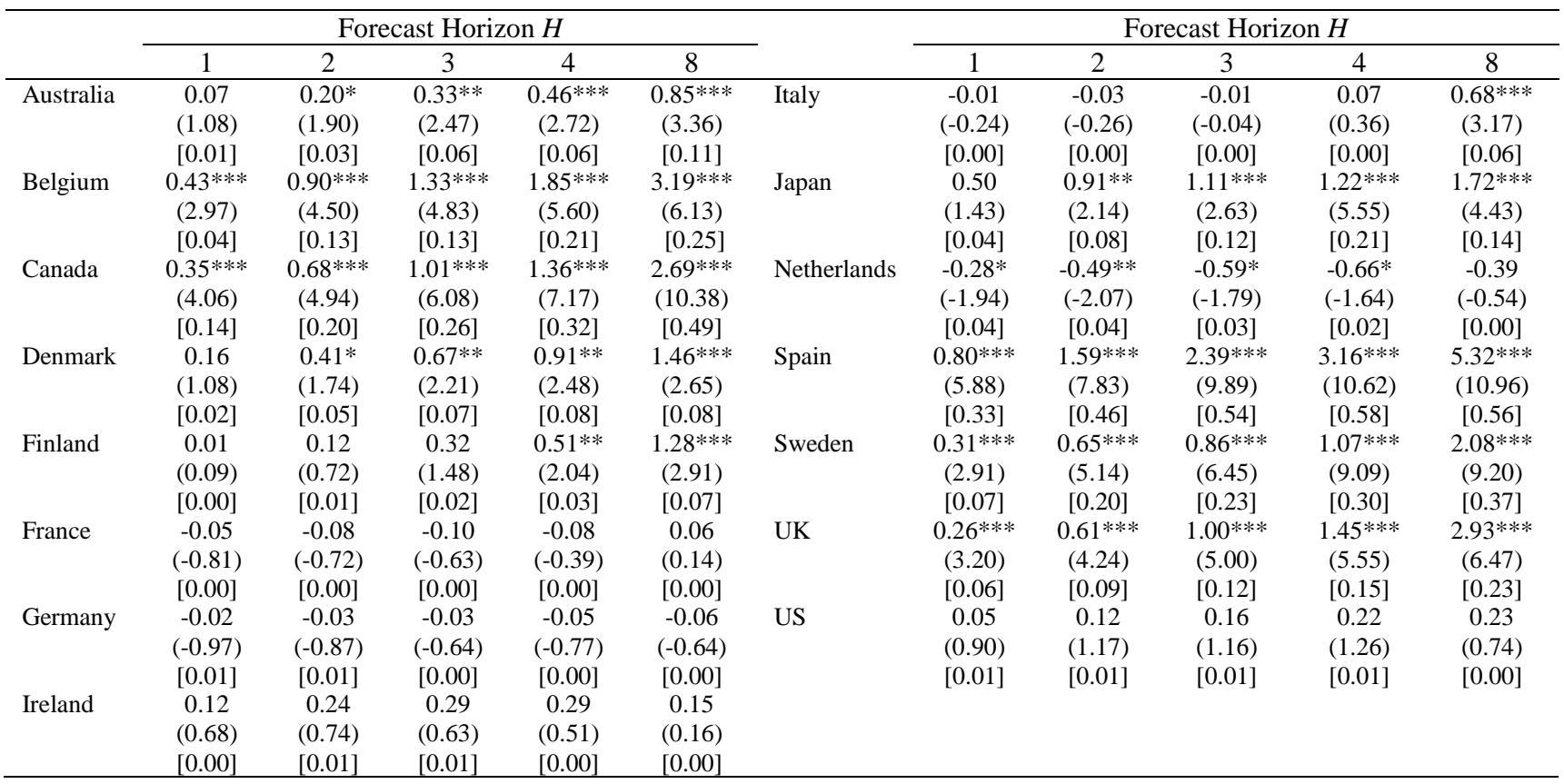

Notes: Newey-West (1987) corrected t-statistics appear in parenthesis. Adjusted R-square is reported in square brackets. *, **, *** denote statistical significance at the 10,5 , and $1 \%$ level, respectively.

Table 4 - Forecasting excess housing returns using cay.

\begin{tabular}{|c|c|c|c|c|c|c|c|c|c|c|c|}
\hline & \multicolumn{5}{|c|}{ Forecast Horizon $H$} & & \multicolumn{5}{|c|}{ Forecast Horizon $H$} \\
\hline & 1 & 2 & 3 & 4 & 8 & & 1 & 2 & 3 & 4 & 8 \\
\hline \multirow[t]{3}{*}{ Australia } & $-0.13^{* *}$ & $-0.21^{*}$ & $-0.28 *$ & $-0.35^{*}$ & $-0.75 * * *$ & Italy & 0.08 & 0.15 & 0.24 & 0.40 & $1.10 * * *$ \\
\hline & $(-2.03)$ & $(-1.861)$ & $(-1.76)$ & $(-1.70)$ & $(-2.53)$ & & (1.13) & $(1.16)$ & $(1.30)$ & $(1.61)$ & $(2.91)$ \\
\hline & [0.03] & {$[0.02]$} & [0.02] & {$[0.02]$} & {$[0.05]$} & & {$[0.01]$} & {$[0.01]$} & {$[0.01]$} & {$[0.02]$} & {$[0.07]$} \\
\hline \multirow[t]{3}{*}{ Belgium } & $0.50 * * *$ & $0.98 * * *$ & $1.49 * * *$ & $2.02 * * *$ & $3.49 * * *$ & Japan & $0.51 * * *$ & $0.99 * * *$ & $1.44 * * *$ & $1.85^{* * *}$ & $2.95 * * *$ \\
\hline & $(4.10)$ & $(4.42)$ & $(4.71)$ & $(4.93)$ & $(5.09)$ & & $(5.94)$ & (5.95) & $(6.07)$ & $(6.20)$ & $(6.05)$ \\
\hline & {$[0.17]$} & {$[0.22]$} & {$[0.25]$} & [0.28] & [0.29] & & [0.38] & [0.39] & [0.39] & [0.39] & [0.36] \\
\hline \multirow[t]{3}{*}{ Canada } & $0.45^{* * *}$ & $0.88 * * *$ & $1.33^{* * *}$ & $1.80^{* * *}$ & $3.54 * * *$ & Netherlands & $-0.64 * * *$ & $-1.22 * * *$ & $-1.73^{* * *}$ & $-2.20 * * *$ & $-3.06 * * *$ \\
\hline & $(4.74)$ & $(5.76)$ & (6.89) & $(7.85)$ & $(10.83)$ & & $(-4.45)$ & $(-4.61)$ & $(-4.37)$ & $(-4.14)$ & $(-3.14)$ \\
\hline & [0.17] & [0.23] & {$[0.29]$} & [0.33] & {$[0.46]$} & & [0.17] & [0.17] & {$[0.16]$} & [0.16] & {$[0.10]$} \\
\hline \multirow[t]{3}{*}{ Denmark } & 0.24 & $0.55^{* *}$ & $0.89 * * *$ & $1.25^{* * *}$ & $1.98 * * *$ & Spain & $0.81^{* * *}$ & $1.62 * * *$ & $2.42 * * *$ & $3.20 * * *$ & $5.42 * * *$ \\
\hline & $(1.60)$ & (2.35) & $(2.65)$ & $(2.98)$ & $(2.95)$ & & $(6.09)$ & $(7.48)$ & $(8.21)$ & (8.17) & (7.58) \\
\hline & [0.05] & [0.08] & {$[0.10]$} & [0.13] & [0.12] & & {$[0.30]$} & [0.37] & {$[0.41]$} & {$[0.42]$} & [0.35] \\
\hline \multirow[t]{3}{*}{ Finland } & 0.08 & 0.26 & $0.54 * *$ & $0.85 * * *$ & $2.21^{* * *}$ & Sweden & $0.24 * * *$ & $0.49 * * *$ & $0.73^{* * *}$ & $0.98 * * *$ & $2.09 * * *$ \\
\hline & $(0.81)$ & $(1.52)$ & $(2.31)$ & (3.01) & $(4.27)$ & & $(4.62)$ & $(5.85)$ & (6.18) & $(6.01)$ & $(5.77)$ \\
\hline & [0.01] & [0.02] & [0.04] & {$[0.06]$} & [0.14] & & [0.13] & [0.15] & {$[0.16]$} & [0.16] & {$[0.24]$} \\
\hline \multirow[t]{2}{*}{ France } & $-0.32 * * *$ & $-0.63 * * *$ & $-0.94 * * *$ & $-1.19 * * *$ & $-2.19 * * *$ & UK & $0.18 * * *$ & $0.44 * * *$ & $0.71 * *$ & $1.01 * * *$ & $1.79 * * *$ \\
\hline & [0.11] & [0.12] & [0.12] & [0.11] & {$[0.10]$} & & [0.03] & [0.05] & {$[0.06]$} & {$[0.08]$} & [0.09] \\
\hline \multirow[t]{3}{*}{ Germany } & -0.02 & -0.04 & -0.06 & -0.08 & -0.12 & US & 0.12 & $0.24 *$ & $0.33 *$ & 0.42 & 0.29 \\
\hline & $(-1.23)$ & $(-1.25)$ & $(-1.41)$ & $(-1.55)$ & $(-1.57)$ & & (1.58) & (1.72) & (1.66) & (1.61) & $(0.61)$ \\
\hline & [0.03] & [0.03] & [0.03] & [0.04] & [0.04] & & [0.02] & [0.03] & [0.02] & {$[0.02]$} & [0.00] \\
\hline \multirow[t]{3}{*}{ Ireland } & 0.21 & 0.35 & 0.21 & -0.06 & -1.26 & & & & & & \\
\hline & (1.05) & (1.04) & $(0.40)$ & $(-0.08)$ & $(-1.03)$ & & & & & & \\
\hline & {$[0.02]$} & [0.03] & {$[0.00]$} & {$[0.00]$} & {$[0.03]$} & & & & & & \\
\hline
\end{tabular}

Notes: Newey-West (1987) corrected t-statistics appear in parenthesis. Adjusted R-square is reported in square brackets. *,**,*** denote statistical significance at the 10,5 , and $1 \%$ level, respectively. 
Table 5 - Testing for Stambaugh (1999) bias: forecasting regressions using cay.

\begin{tabular}{|c|c|c|c|c|c|c|c|c|c|c|c|}
\hline \multirow[b]{2}{*}{ Real housing returns } & \multicolumn{5}{|c|}{ Forecast Horizon $H$} & \multirow[b]{2}{*}{ Excess housing returns } & \multicolumn{5}{|c|}{ Forecast Horizon $H$} \\
\hline & 1 & 2 & 3 & 4 & 8 & & 1 & 2 & 3 & 4 & 8 \\
\hline Australia & -0.01 & -0.02 & -0.02 & -0.02 & -0.01 & Australia & -0.02 & -0.03 & -0.03 & -0.03 & -0.02 \\
\hline Belgium & -0.01 & -0.02 & -0.02 & -0.02 & -0.01 & Belgium & -0.01 & -0.01 & -0.02 & -0.02 & -0.01 \\
\hline Canada & -0.00 & 0.01 & 0.01 & 0.01 & 0.03 & Canada & -0.01 & 0.00 & 0.01 & 0.01 & 0.04 \\
\hline Denmark & 0.01 & 0.00 & 0.00 & 0.01 & 0.05 & Denmark & 0.01 & 0.00 & 0.01 & 0.01 & 0.04 \\
\hline Finland & -0.04 & -0.08 & -0.11 & -0.10 & -0.08 & Finland & -0.05 & -0.09 & -0.12 & -0.13 & -0.11 \\
\hline France & -0.00 & -0.01 & -0.01 & -0.02 & -0.01 & France & -0.01 & -0.02 & -0.02 & -0.03 & -0.04 \\
\hline Germany & -0.00 & -0.01 & -0.01 & -0.01 & -0.01 & Germany & -0.00 & -0.01 & -0.01 & -0.01 & -0.01 \\
\hline Ireland & 0.02 & 0.02 & 0.03 & 0.04 & 0.06 & Ireland & -0.01 & -0.01 & -0.01 & -0.01 & -0.16 \\
\hline Italy & 0.01 & 0.03 & 0.04 & 0.03 & -0.02 & Italy & 0.01 & 0.01 & -0.00 & -0.03 & -0.03 \\
\hline Japan & 0.01 & 0.02 & 0.03 & 0.03 & 0.05 & Japan & 0.01 & 0.01 & 0.02 & 0.03 & 0.06 \\
\hline Netherlands & -0.01 & -0.01 & -0.02 & -0.02 & -0.04 & Netherlands & -0.01 & -0.03 & -0.04 & -0.05 & -0.08 \\
\hline Spain & 0.00 & -0.00 & -0.00 & 0.03 & 0.15 & Spain & 0.01 & 0.02 & 0.03 & 0.07 & 0.20 \\
\hline Sweden & -0.02 & -0.03 & 0.01 & 0.02 & 0.02 & Sweden & -0.01 & 0.00 & 0.00 & 0.00 & 0.00 \\
\hline UK & -0.01 & -0.02 & -0.02 & -0.02 & 0.03 & UK & -0.01 & -0.02 & -0.02 & -0.02 & 0.02 \\
\hline US & -0.00 & -0.00 & 0.00 & -0.00 & 0.01 & US & -0.00 & 0.00 & 0.01 & 0.01 & 0.02 \\
\hline
\end{tabular}

Notes: The magnitude of the bias is, approximately, equal to $\gamma /(1+3 \rho) / T$, under the normality assumption, where $\gamma$ is the coefficient from regressing the residual in the returns regression on the residual from an AR(1) regression for the forecasting variable (cay), $\rho$ is the AR coefficient for the forecasting variable (cay), and $T$ is the sample size. (Stambaugh, 1999).

Table 6 - Forecasting real housing returns using re-estimated cay.

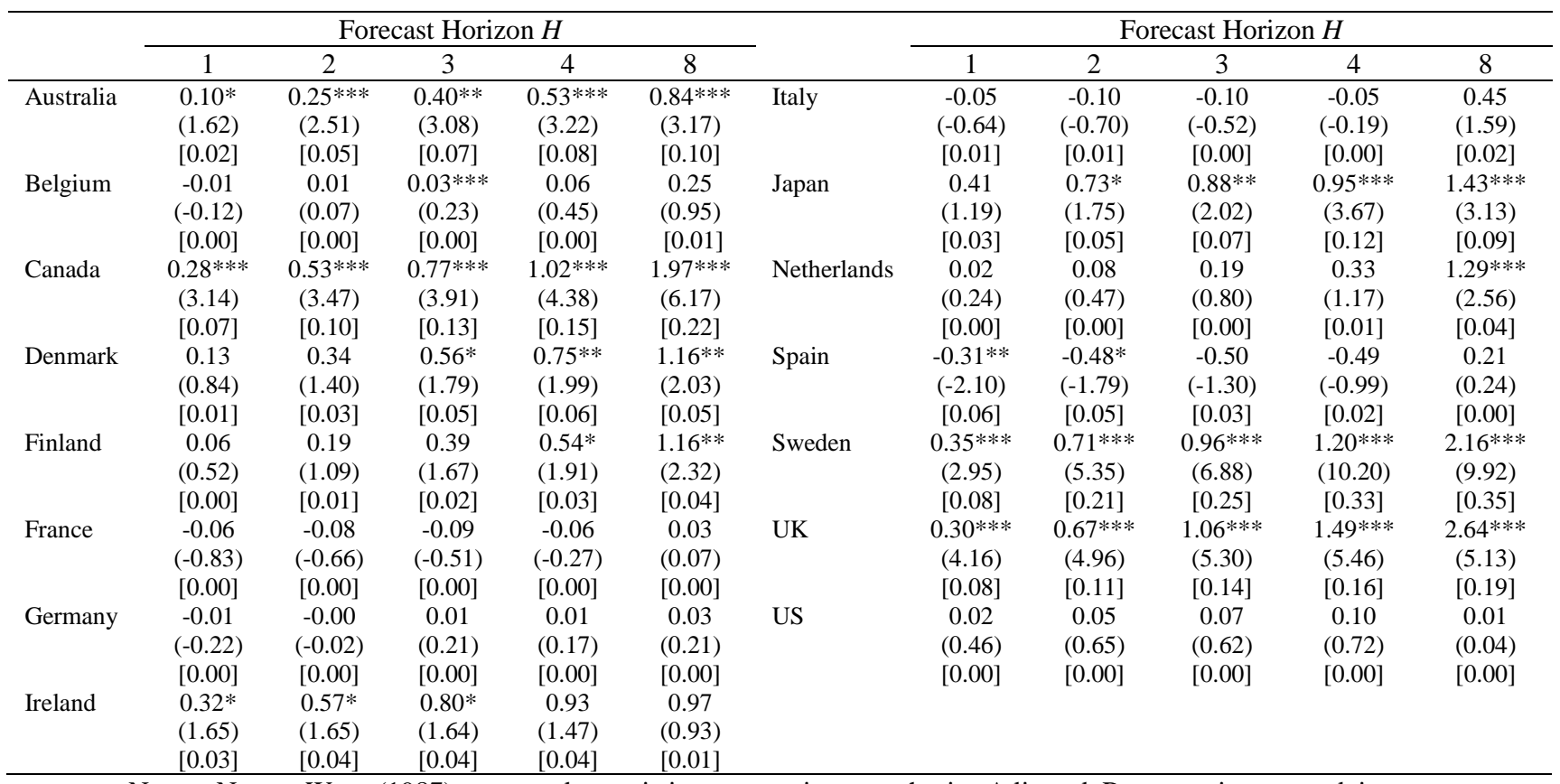

Notes: Newey-West (1987) corrected t-statistics appear in parenthesis. Adjusted R-square is reported in square brackets. *, **, *** denote statistical significance at the 10,5 , and $1 \%$ level, respectively. 
Table 7 - Forecasting excess housing returns using re-estimated cay.

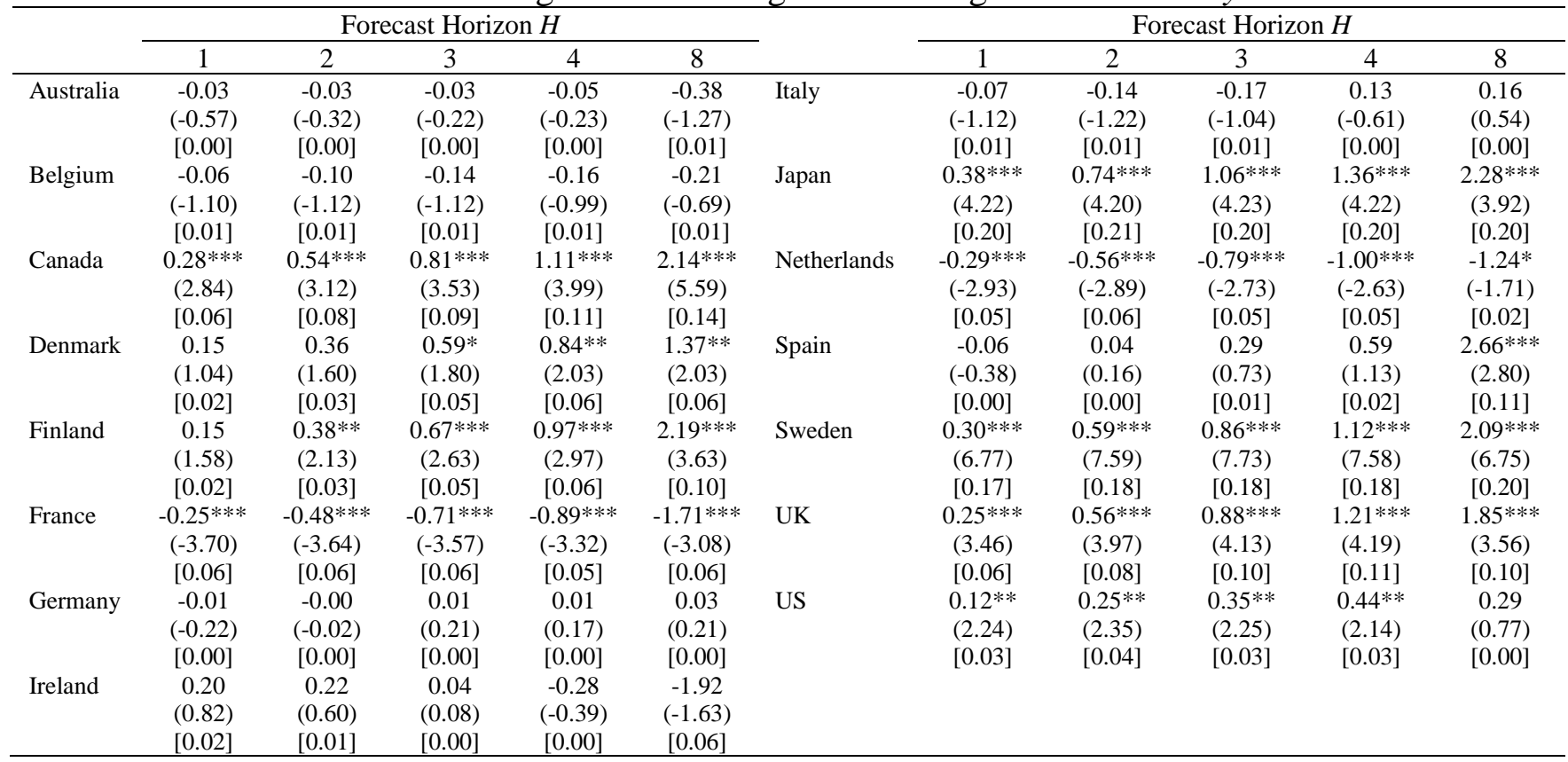

Notes: Newey-West (1987) corrected t-statistics appear in parenthesis. Adjusted R-square is reported in square brackets. *, **, *** denote statistical significance at the 10,5 , and $1 \%$ level, respectively.

Table 8 - Forecasting real housing returns using cay and additional control variables.

\begin{tabular}{|c|c|c|c|c|c|c|c|c|}
\hline & $H R_{t-1}$ & cayt -1 & $\operatorname{RentYld}_{t-1}$ & $\begin{array}{c}\text { Adj. } \\
\text { R-square }\end{array}$ & $H R_{t-1}$ & cayt $-1_{1}$ & Inflation $_{t-1}$ & $\begin{array}{c}\text { Adj. } \\
\text { R-square }\end{array}$ \\
\hline Australia & $\begin{array}{l}-0.61 * * \\
(-1.95)\end{array}$ & $\begin{array}{c}0.82 * * * \\
(3.49)\end{array}$ & $\begin{array}{l}6.63^{* *} \\
(1.90)\end{array}$ & {$[0.16]$} & $\begin{array}{l}-0.57^{*} \\
(-1.91)\end{array}$ & $\begin{array}{c}0.83 * * * \\
(2.87)\end{array}$ & $\begin{array}{c}-0.00 \\
(-0.83)\end{array}$ & [0.14] \\
\hline Belgium & $\begin{array}{l}0.66^{* *} \\
(2.27)\end{array}$ & $\begin{array}{c}2.63 * * * \\
(5.35)\end{array}$ & $\begin{array}{c}7.59 * * \\
(2.40)\end{array}$ & [0.33] & $\begin{array}{c}2.15 * * * \\
(2.86)\end{array}$ & $\begin{array}{c}2.43^{* * * *} \\
(5.22)\end{array}$ & $\begin{array}{c}0.02 * * * \\
(2.54)\end{array}$ & {$[0.36]$} \\
\hline Canada & $\begin{array}{c}0.15 \\
(0.60)\end{array}$ & $\begin{array}{c}2.19 * * * \\
(9.22)\end{array}$ & $\begin{array}{c}12.16^{* * *} \\
(6.48)\end{array}$ & {$[0.62]$} & $\begin{array}{c}0.40 \\
(1.57)\end{array}$ & $\begin{array}{c}2.98 * * * \\
(10.84)\end{array}$ & $\begin{array}{c}0.02 * * * \\
(3.70)\end{array}$ & {$[0.54]$} \\
\hline Denmark & $\begin{array}{c}0.30 \\
(0.79)\end{array}$ & $\begin{array}{c}1.19 * * * \\
(2.98)\end{array}$ & $\begin{array}{c}40.04^{* * * *} \\
(8.86)\end{array}$ & [0.47] & $\begin{array}{c}0.72 \\
(1.29)\end{array}$ & $\begin{array}{l}1.28 * * \\
(2.24)\end{array}$ & $\begin{array}{c}0.00 \\
(0.02)\end{array}$ & {$[0.10]$} \\
\hline Finland & $\begin{array}{c}0.98 * * * \\
(2.65)\end{array}$ & $\begin{array}{c}1.16^{* * *} \\
(3.38)\end{array}$ & $\begin{array}{c}31.74^{* * * *} \\
(8.37)\end{array}$ & [0.39] & $\begin{array}{c}2.50 * * * \\
(4.20)\end{array}$ & $\begin{array}{c}2.27 * * * \\
(4.65)\end{array}$ & $\begin{array}{c}0.03 * * * \\
(4.16)\end{array}$ & {$[0.26]$} \\
\hline France & $\begin{array}{c}1.93 * * * \\
(3.94)\end{array}$ & $\begin{array}{c}-0.07 \\
(-0.20)\end{array}$ & $\begin{array}{c}28.78 * * * \\
(6.90)\end{array}$ & [0.35] & $\begin{array}{c}1.98 * * * \\
(3.59)\end{array}$ & $\begin{array}{l}-0.16 \\
(-0.35)\end{array}$ & $\begin{array}{c}-0.01 \\
(-1.52)\end{array}$ & {$[0.16]$} \\
\hline Germany & $\begin{array}{c}0.95 * * \\
(2.13)\end{array}$ & $\begin{array}{c}-0.16 \\
(-1.42)\end{array}$ & $\begin{array}{l}8.74^{*} \\
(1.89)\end{array}$ & [0.07] & $\begin{array}{c}1.64 * * * \\
(4.16)\end{array}$ & $\begin{array}{c}0.09 \\
(0.85)\end{array}$ & $\begin{array}{c}0.01 * * * \\
(2.50)\end{array}$ & {$[0.10]$} \\
\hline Ireland & $\begin{array}{c}0.09 \\
(0.95)\end{array}$ & $\begin{array}{c}-0.12 \\
(-0.62)\end{array}$ & $\begin{array}{c}1.69 * * \\
(2.42)\end{array}$ & [0.13] & & & & \\
\hline Italy & $\begin{array}{c}0.56 \\
(1.61)\end{array}$ & $\begin{array}{c}-0.80 * * * \\
(-3.74)\end{array}$ & $\begin{array}{c}69.86 * * * \\
(9.72)\end{array}$ & {$[0.71]$} & $\begin{array}{c}1.21^{* * * *} \\
(2.86)\end{array}$ & $\begin{array}{c}0.48 * * \\
(2.25)\end{array}$ & $\begin{array}{c}-0.03^{* *} \\
(-2.46)\end{array}$ & {$[0.22]$} \\
\hline Japan & $\begin{array}{c}0.05 \\
(0.25)\end{array}$ & $\begin{array}{l}0.78^{*} \\
(1.71)\end{array}$ & $\begin{array}{c}47.32 * * * \\
(4.58)\end{array}$ & {$[0.24]$} & $\begin{array}{c}-0.15 \\
(-0.20)\end{array}$ & $\begin{array}{c}1.77 * * * \\
(3.93)\end{array}$ & $\begin{array}{c}-0.00 \\
(-0 . .26)\end{array}$ & {$[0.15]$} \\
\hline Netherlands & $\begin{array}{c}2.38 * * * \\
(4.30)\end{array}$ & $\begin{array}{c}0.26 \\
(0.48)\end{array}$ & $\begin{array}{c}19.93 * * * \\
(6.90)\end{array}$ & {$[0.53]$} & $\begin{array}{c}3.19 * * * \\
(3.46)\end{array}$ & $\begin{array}{l}1.46^{*} \\
(1.85)\end{array}$ & $\begin{array}{c}-0.01 \\
(-0.35)\end{array}$ & {$[0.28]$} \\
\hline Spain & $\begin{array}{c}1.18^{* * * *} \\
(3.08)\end{array}$ & $\begin{array}{c}3.96 * * * \\
(5.42)\end{array}$ & $\begin{array}{c}6.31 \\
(0.87)\end{array}$ & {$[0.60]$} & $\begin{array}{l}1.02^{* *} \\
(2.49)\end{array}$ & $\begin{array}{c}4.30^{* * * *} \\
(5.94)\end{array}$ & $\begin{array}{c}-0.01 \\
(-0.94)\end{array}$ & {$[0.60]$} \\
\hline Sweden & $\begin{array}{l}0.44^{*} \\
(1.84)\end{array}$ & $\begin{array}{c}0.45 \\
(1.03)\end{array}$ & $\begin{array}{c}24.57 * * * \\
(4.54)\end{array}$ & {$[0.46]$} & $\begin{array}{l}1.43^{* *} \\
(2.42)\end{array}$ & $\begin{array}{c}1.76^{* * *} \\
(7.12)\end{array}$ & $\begin{array}{l}0.01 * \\
(1.74)\end{array}$ & {$[0.40]$} \\
\hline UK & $\begin{array}{l}0.78^{*} \\
(1.64)\end{array}$ & $\begin{array}{c}-0.23 \\
(-0.32)\end{array}$ & $\begin{array}{c}49.65^{* * *} \\
(5.72)\end{array}$ & [0.45] & $\begin{array}{c}0.69 \\
(1.27)\end{array}$ & $\begin{array}{c}2.52^{* * *} \\
(4.67)\end{array}$ & $\begin{array}{l}-0.02^{*} \\
(-1.88)\end{array}$ & [0.29] \\
\hline US & $\begin{array}{c}1.77 * * * \\
(4.01)\end{array}$ & $\begin{array}{c}-0.06 \\
(-0.24)\end{array}$ & $\begin{array}{c}23.91 * * * \\
(4.54)\end{array}$ & {$[0.25]$} & $\begin{array}{c}0.66 \\
(1.34)\end{array}$ & $\begin{array}{c}-0.24 \\
(-1.01)\end{array}$ & $\begin{array}{c}-0.04 * * * \\
(-5.05)\end{array}$ & {$[0.29]$} \\
\hline
\end{tabular}

Notes: Newey-West (1987) corrected t-statistics appear in parenthesis. Adjusted R-square is reported in square brackets. $*, * *, * * *$ denote statistical significance at the 10, 5, and $1 \%$ level, respectively. 
Table 9 - Forecasting excess housing returns using cay and additional control variables.

\begin{tabular}{|c|c|c|c|c|c|c|c|c|}
\hline & $E R_{t-1}$ & cayt -1 & $\operatorname{RentYld}_{t-1}$ & $\begin{array}{c}\text { Adj. } \\
\text { R-square }\end{array}$ & $E R_{t-1}$ & cayt -1 & Inflation $_{t-1}$ & $\begin{array}{c}\text { Adj. } \\
\text { R-square }\end{array}$ \\
\hline Australia & $\begin{array}{l}-0.84^{*} \\
(-1.65)\end{array}$ & $\begin{array}{c}-1.08 * * * \\
(-4.30)\end{array}$ & $\begin{array}{c}25.16 * * * \\
(4.89)\end{array}$ & {$[0.21]$} & $\begin{array}{c}-0.09 \\
(-0.16)\end{array}$ & $\begin{array}{l}-0.53^{*} \\
(-1.64)\end{array}$ & $\begin{array}{c}0.01 \\
(1.60)\end{array}$ & {$[0.05]$} \\
\hline Belgium & $\begin{array}{c}2.99 * * * \\
(7.74)\end{array}$ & $\begin{array}{c}1.97 * * * \\
(4.20)\end{array}$ & $\begin{array}{c}0.66 \\
(0.20)\end{array}$ & {$[0.60]$} & $\begin{array}{c}2.95 * * * \\
(7.51)\end{array}$ & $\begin{array}{c}2.02 * * * \\
(4.72)\end{array}$ & $\begin{array}{l}-0.00 \\
(-0.61)\end{array}$ & {$[0.60]$} \\
\hline Canada & $\begin{array}{l}0.48^{*} \\
(1.98)\end{array}$ & $\begin{array}{c}2.67^{* * *} \\
(10.00)\end{array}$ & $\begin{array}{c}19.62 * * * \\
(6.81)\end{array}$ & [0.67] & $\begin{array}{c}0.72 * * * \\
(2.78)\end{array}$ & $\begin{array}{c}3.98^{* * * *} \\
(11.73)\end{array}$ & $\begin{array}{c}0.04 * * * \\
(4.27)\end{array}$ & [0.57] \\
\hline Denmark & $\begin{array}{l}1.00 * * \\
(2.28)\end{array}$ & $\begin{array}{c}1.43^{* * *} \\
(2.52)\end{array}$ & $\begin{array}{c}31.59 * * * \\
(5.18)\end{array}$ & {$[0.36]$} & $\begin{array}{l}1.18^{* *} \\
(2.15)\end{array}$ & $\begin{array}{l}1.26^{*} \\
(1.82)\end{array}$ & $\begin{array}{c}-0.01 \\
(-0.49)\end{array}$ & [0.16] \\
\hline Finland & $\begin{array}{c}2.35^{* * *} \\
(5.17)\end{array}$ & $\begin{array}{c}2.41^{* * *} \\
(6.35)\end{array}$ & $\begin{array}{c}32.89 * * * \\
(7.61)\end{array}$ & {$[0.50]$} & $\begin{array}{c}2.84^{* * *} \\
(4.73)\end{array}$ & $\begin{array}{c}2.93 * * * \\
(5.63)\end{array}$ & $\begin{array}{c}0.01 \\
(0.86)\end{array}$ & {$[0.34]$} \\
\hline France & $\begin{array}{c}3.33^{* * *} \\
(8.28)\end{array}$ & $\begin{array}{c}-1.40 * * * \\
(-3.33)\end{array}$ & $\begin{array}{c}39.32 * * * \\
(8.24)\end{array}$ & {$[0.61]$} & $\begin{array}{c}4.15^{* * *} \\
(8.97)\end{array}$ & $\begin{array}{l}-0.98 * \\
(-1.72)\end{array}$ & $\begin{array}{c}-0.01 \\
(-1.07)\end{array}$ & {$[0.40]$} \\
\hline Germany & $\begin{array}{c}-0.70 \\
(-1.14)\end{array}$ & $\begin{array}{c}-0.01 \\
(-0.10)\end{array}$ & $\begin{array}{c}-7.23 \\
(-1.31)\end{array}$ & [0.07] & $\begin{array}{c}-0.51 \\
(-0.81)\end{array}$ & $\begin{array}{c}-0.08 \\
(-0.96)\end{array}$ & $\begin{array}{c}0.01 * * * \\
(2.67)\end{array}$ & {$[0.14]$} \\
\hline Ireland & $\begin{array}{c}2.04 * * * \\
(3.13)\end{array}$ & $\begin{array}{c}-1.23 \\
(-1.26)\end{array}$ & $\begin{array}{l}-9.31 * \\
(-1.77)\end{array}$ & [0.30] & & & & \\
\hline Italy & $\begin{array}{c}0.00 \\
(0.01)\end{array}$ & $\begin{array}{c}-1.05 * * * \\
(-3.73)\end{array}$ & $\begin{array}{c}61.91 * * * \\
(11.40)\end{array}$ & [0.62] & $\begin{array}{c}1.60 * * * \\
(3.82)\end{array}$ & $\begin{array}{c}0.82 * * * \\
(3.73)\end{array}$ & $\begin{array}{c}-0.03^{* * *} \\
(-2.53)\end{array}$ & [0.32] \\
\hline Japan & $\begin{array}{c}-0.33 \\
(0.53)\end{array}$ & $\begin{array}{c}1.92^{* * *} \\
(3.53)\end{array}$ & $\begin{array}{c}59.48 * * * \\
(7.86)\end{array}$ & [0.49] & $\begin{array}{c}-0.18 \\
(-0.26)\end{array}$ & $\begin{array}{c}3.03 * * * \\
(5.04)\end{array}$ & $\begin{array}{c}-0.00 \\
(-0.03)\end{array}$ & {$[0.36]$} \\
\hline Netherlands & $\begin{array}{c}3.02 * * * \\
(4.84)\end{array}$ & $\begin{array}{c}-1.43 \\
(-1.40)\end{array}$ & $\begin{array}{c}18.14 * * * \\
(5.23)\end{array}$ & {$[0.44]$} & $\begin{array}{c}3.61^{* * *} \\
(4.52)\end{array}$ & $\begin{array}{c}1.29 \\
(1.55)\end{array}$ & $\begin{array}{l}-0.03^{*} \\
(-1.68)\end{array}$ & {$[0.36]$} \\
\hline Spain & $\begin{array}{c}2.43 * * * \\
(3.04)\end{array}$ & $\begin{array}{l}2.41^{* *} \\
(2.19)\end{array}$ & $\begin{array}{c}20.16^{* *} \\
(1.97)\end{array}$ & {$[0.47]$} & $\begin{array}{c}2.23 * * * \\
(2.82)\end{array}$ & $\begin{array}{c}3.16 * * * \\
(2.61)\end{array}$ & $\begin{array}{c}-0.05^{* *} \\
(-2.01)\end{array}$ & {$[0.50]$} \\
\hline Sweden & $\begin{array}{c}2.90 * * * \\
(5.07)\end{array}$ & $\begin{array}{c}-0.60 \\
(-1.04)\end{array}$ & $\begin{array}{c}34.10 * * * \\
(5.60)\end{array}$ & {$[0.46]$} & $\begin{array}{c}2.31 * * * \\
(3.62)\end{array}$ & $\begin{array}{c}1.48^{* * * *} \\
(3.32)\end{array}$ & $\begin{array}{l}-0.00 \\
(-0.64)\end{array}$ & [0.34] \\
\hline UK & $\begin{array}{c}1.19 * * * \\
(2.53)\end{array}$ & $\begin{array}{c}-1.52^{* *} \\
(-2.21)\end{array}$ & $\begin{array}{c}53.29 * * * \\
(5.51)\end{array}$ & {$[0.40]$} & $\begin{array}{c}1.60 * * * \\
(3.04)\end{array}$ & $\begin{array}{c}1.67 * * * \\
(3.49)\end{array}$ & $\begin{array}{c}-0.01 \\
(-0.84)\end{array}$ & [0.18] \\
\hline US & $\begin{array}{c}3.87 * * * \\
(7.96) \\
\end{array}$ & $\begin{array}{c}-0.11 \\
(-0.29)\end{array}$ & $\begin{array}{c}23.91 * * * \\
(2.86)\end{array}$ & [0.34] & $\begin{array}{c}3.12^{* * * *} \\
(6.28)\end{array}$ & $\begin{array}{c}-0.23 \\
(-0.71)\end{array}$ & $\begin{array}{c}-0.04 * * * \\
(-2.92)\end{array}$ & [0.36] \\
\hline
\end{tabular}

Notes: Newey-West (1987) corrected t-statistics appear in parenthesis. Adjusted R-square is reported in square brackets. $*, * *, * * *$ denote statistical significance at the 10,5 , and $1 \%$ level, respectively.

Table 10 - Forecasting consumption growth using cay.

\begin{tabular}{|c|c|c|c|c|c|c|c|c|c|c|c|}
\hline & \multicolumn{5}{|c|}{ Forecast Horizon $H$} & & \multicolumn{5}{|c|}{ Forecast Horizon $H$} \\
\hline & 1 & 2 & 3 & 4 & 8 & & 1 & 2 & 3 & 4 & 8 \\
\hline Australia & $\begin{array}{l}-0.04^{*} \\
(-1.67)\end{array}$ & $\begin{array}{c}-0.02 \\
(-0.79)\end{array}$ & $\begin{array}{c}-0.01 \\
(-0.42)\end{array}$ & $\begin{array}{c}0.00 \\
(0.11)\end{array}$ & $\begin{array}{c}0.02 \\
(0.90)\end{array}$ & Italy & $\begin{array}{c}-0.00 \\
(-0.33)\end{array}$ & $\begin{array}{c}0.00 \\
(0.01)\end{array}$ & $\begin{array}{c}0.01 \\
(0.50)\end{array}$ & $\begin{array}{c}0.01 \\
(0.78)\end{array}$ & $\begin{array}{c}-0.00 \\
(-0.28)\end{array}$ \\
\hline Belgium & $\begin{array}{c}{[0.03]} \\
-0.01\end{array}$ & $\begin{array}{c}{[0.01]} \\
-0.05\end{array}$ & $\begin{array}{c}{[0.00]} \\
-0.08^{* *}\end{array}$ & $\begin{array}{c}{[0.00]} \\
-0.04\end{array}$ & $\begin{array}{c}{[0.01]} \\
0.09^{* * *}\end{array}$ & Japan & $\begin{array}{c}{[0.00]} \\
0.04\end{array}$ & $\begin{array}{c}{[0.00]} \\
0.05\end{array}$ & $\begin{array}{c}{[0.00]} \\
0.01\end{array}$ & $\begin{array}{c}{[0.01]} \\
0.05\end{array}$ & $\begin{array}{l}{[0.00]} \\
-0.02\end{array}$ \\
\hline & $\begin{array}{c}(-0.26) \\
{[0.00]}\end{array}$ & $\begin{array}{l}(-1.18) \\
{[0.03]}\end{array}$ & $\begin{array}{l}(-1.99) \\
{[0.07]}\end{array}$ & $\begin{array}{c}(-0.88) \\
{[0.01]}\end{array}$ & $\begin{array}{l}(3.82) \\
{[0.09]}\end{array}$ & & $\begin{array}{l}(1.02) \\
{[0.01]}\end{array}$ & $\begin{array}{l}(1.34) \\
{[0.01]}\end{array}$ & $\begin{array}{l}(0.13) \\
{[0.00]}\end{array}$ & $\begin{array}{l}(0.83) \\
{[0.01]}\end{array}$ & $\begin{array}{l}(-0.28) \\
{[0.00]}\end{array}$ \\
\hline Canada & $\begin{array}{c}0.14^{* * *} \\
(5.07) \\
{[0.18]}\end{array}$ & $\begin{array}{c}0.13^{* * *} \\
(4.89) \\
{[0.17]}\end{array}$ & $\begin{array}{c}0.12 * * * \\
(4.53) \\
{[0.15]}\end{array}$ & $\begin{array}{c}0.12^{* * *} \\
(3.90) \\
{[0.14]}\end{array}$ & $\begin{array}{c}0.07 * * * \\
(2.52) \\
{[0.05]}\end{array}$ & Netherlands & $\begin{array}{c}-0.13 * * * \\
(-2.79) \\
{[0.07]}\end{array}$ & $\begin{array}{c}-0.12 * * \\
(-2.34) \\
{[0.06]}\end{array}$ & $\begin{array}{c}-0.09 * \\
(-1.75) \\
{[0.03]}\end{array}$ & $\begin{array}{c}-0.07 \\
(-1.50) \\
{[0.02]}\end{array}$ & $\begin{array}{c}-0.02 \\
(-0.42) \\
{[0.00]}\end{array}$ \\
\hline Denmark & $\begin{array}{c}0.04 \\
(0.71) \\
{[0.01]}\end{array}$ & $\begin{array}{c}0.04 \\
(0.74) \\
{[0.01]}\end{array}$ & $\begin{array}{l}-0.00 \\
(-0.07) \\
{[0.00]}\end{array}$ & $\begin{array}{c}0.03 \\
(0.74) \\
{[0.00]}\end{array}$ & $\begin{array}{c}0.00 \\
(0.25) \\
{[0.00]}\end{array}$ & Spain & $\begin{array}{c}0.12^{* * *} \\
(2.62) \\
{[0.09]}\end{array}$ & $\begin{array}{c}0.14^{* * *} \\
(3.16) \\
{[0.13]}\end{array}$ & $\begin{array}{c}0.15^{* * *} \\
(3.32) \\
{[0.14]}\end{array}$ & $\begin{array}{c}0.18^{* * *} \\
(4.13) \\
{[0.21]}\end{array}$ & $\begin{array}{c}0.12 * * * \\
(2.86) \\
{[0.09]}\end{array}$ \\
\hline Finland & $\begin{array}{c}-0.01 \\
(-0.40) \\
{[0.00]}\end{array}$ & $\begin{array}{c}0.02 \\
(0.52) \\
{[0.00]}\end{array}$ & $\begin{array}{c}0.04 \\
(1.49) \\
{[0.02]}\end{array}$ & $\begin{array}{l}0.06^{* *} \\
(2.14) \\
{[0.05]}\end{array}$ & $\begin{array}{c}0.10^{* * *} \\
(3.89) \\
{[0.12]}\end{array}$ & Sweden & $\begin{array}{c}0.04 * * * \\
(2.58) \\
{[0.05]}\end{array}$ & $\begin{array}{l}0.03 * * \\
(2.21) \\
{[0.04]}\end{array}$ & $\begin{array}{c}0.03 * * \\
(2.08) \\
{[0.03]}\end{array}$ & $\begin{array}{l}0.03 * * \\
(2.04) \\
{[0.03]}\end{array}$ & $\begin{array}{c}0.06 * * * \\
(2.95) \\
{[0.11]}\end{array}$ \\
\hline France & $\begin{array}{c}-0.05 \\
(-1.41) \\
{[0.02]}\end{array}$ & $\begin{array}{c}-0.08^{* *} \\
(-2.06) \\
{[0.03]}\end{array}$ & $\begin{array}{l}-0.07 * \\
(-1.81) \\
{[0.02]}\end{array}$ & $\begin{array}{c}-0.03 \\
(-0.75) \\
{[0.00]}\end{array}$ & $\begin{array}{c}0.01 \\
(0.18) \\
{[0.00]}\end{array}$ & UK & $\begin{array}{c}0.10^{* * *} \\
(3.62) \\
{[0.06]}\end{array}$ & $\begin{array}{c}0.09 * * * \\
(3.42) \\
{[0.05]}\end{array}$ & $\begin{array}{c}0.08^{* * * *} \\
(3.05) \\
{[0.04]}\end{array}$ & $\begin{array}{c}0.12^{* * *} \\
(4.25) \\
{[0.08]}\end{array}$ & $\begin{array}{l}0.06^{* *} \\
(2.05) \\
{[0.02]}\end{array}$ \\
\hline Germany & $\begin{array}{c}0.01 \\
(0.36) \\
{[0.00]}\end{array}$ & $\begin{array}{c}0.05 \\
(1.42) \\
{[0.02]}\end{array}$ & $\begin{array}{c}0.04 \\
(1.08) \\
{[0.01]}\end{array}$ & $\begin{array}{c}0.02 \\
(0.80) \\
{[0.00]}\end{array}$ & $\begin{array}{c}0.03 \\
(0.78) \\
{[0.01]}\end{array}$ & US & $\begin{array}{c}0.02 \\
(0.44) \\
{[0.00]}\end{array}$ & $\begin{array}{c}0.02 \\
(0.54) \\
{[0.00]}\end{array}$ & $\begin{array}{c}-0.01 \\
(-0.34) \\
{[0.00]}\end{array}$ & $\begin{array}{c}0.00 \\
(0.03) \\
{[0.00]}\end{array}$ & $\begin{array}{c}0.00 \\
(0.08) \\
{[0.00]}\end{array}$ \\
\hline Ireland & $\begin{array}{c}-0.06 \\
(-0.80) \\
{[0.01]}\end{array}$ & $\begin{array}{c}-0.07 \\
(-1.09) \\
{[0.02]}\end{array}$ & $\begin{array}{c}-0.04 \\
(-0.65) \\
{[0.00]}\end{array}$ & $\begin{array}{c}-0.01 \\
(-0.13) \\
{[0.00]}\end{array}$ & $\begin{array}{c}-0.00 \\
(-0.02) \\
{[0.00]}\end{array}$ & & & & & & \\
\hline
\end{tabular}

Notes: Newey-West (1987) corrected t-statistics appear in parenthesis. Adjusted R-square is reported in square brackets. *,**,** denote statistical significance at the 10,5 , and $1 \%$ level, respectively. 
Table 11 - One-quarter ahead forecasts of returns: cay model vs. constant/AR models.

\begin{tabular}{lcccc}
\hline & \multicolumn{2}{c}{ Real housing returns } & \multicolumn{2}{c}{ Excess housing returns } \\
\cline { 2 - 5 } & $\mathrm{MSE}_{\text {cay }} / \mathrm{MSE}_{\text {constant }}$ & $\mathrm{MSE}_{\text {cay }} / \mathrm{MSE}_{\mathrm{AR}}$ & $\mathrm{MSE}_{\text {cay }} / \mathrm{MSE}_{\text {constant }}$ & $\mathrm{MSE}_{\text {cay }} / \mathrm{MSE}_{\mathrm{AR}}$ \\
\hline Australia & 0.999 & 1.002 & 0.991 & 1.005 \\
Belgium & 0.985 & 0.990 & 0.918 & 0.973 \\
Canada & 0.930 & 0.940 & 0.912 & 0.915 \\
Denmark & 0.995 & 1.003 & 0.982 & 0.999 \\
Finland & 1.005 & 1.003 & 1.002 & 0.951 \\
France & 1.002 & 1.001 & 0.945 & 0.999 \\
Germany & 1.001 & 1.004 & 0.997 & 0.996 \\
Ireland & 1.004 & 0.998 & 0.998 & 0.988 \\
Italy & 1.006 & 1.004 & 1.000 & 1.004 \\
Japan & 0.984 & 0.960 & 0.789 & 0.910 \\
Netherlands & 0.986 & 0.987 & 0.917 & 1.003 \\
Spain & 0.823 & 0.969 & 0.844 & 0.955 \\
Sweden & 0.971 & 0.979 & 0.939 & 0.985 \\
UK & 0.974 & 0.980 & 0.988 & 0.972 \\
US & 1.000 & 1.002 & 0.992 & 1.000 \\
\hline
\end{tabular}

Note: MSE represents the mean-squared forecasting error. 
Table 12 - Correlations between real housing returns and country characteristics.

\begin{tabular}{|c|c|c|c|c|c|c|c|c|c|c|c|}
\hline & \multicolumn{5}{|c|}{ Forecast Horizon $H$} & & \multicolumn{5}{|c|}{ Forecast Horizon $H$} \\
\hline & 1 & 2 & 3 & 4 & 8 & & 1 & 2 & 3 & 4 & 8 \\
\hline \multicolumn{7}{|c|}{ Australia } & \multicolumn{5}{|c|}{ Ireland } \\
\hline RF & $-0.16^{* *}$ & $-0.19 * *$ & $-0.19 * *$ & $-0.18 * *$ & -0.02 & RF & -0.11 & -0.13 & $-0.18 * *$ & $-0.24 * * *$ & $-0.36 * * *$ \\
\hline GDP & 0.01 & 0.02 & 0.03 & 0.03 & 0.03 & GDP & $-0.26 *$ & $-0.37 * *$ & $-0.48 * * *$ & $-0.60 * * *$ & $-0.80 * * *$ \\
\hline GROWTH & 0.01 & 0.02 & 0.03 & 0.03 & 0.01 & GROWTH & $-0.46 * * *$ & $-0.55 * * *$ & $-0.63 * * *$ & $-0.71 * * *$ & $-0.87 * * *$ \\
\hline LEV & -0.01 & -0.00 & -0.00 & -0.00 & -0.01 & LEV & 0.01 & 0.01 & 0.03 & 0.04 & 0.03 \\
\hline POP & 0.02 & 0.03 & 0.04 & 0.04 & 0.05 & POP & -0.12 & -0.13 & -0.12 & -0.11 & -0.10 \\
\hline INFL & $-0.15^{*}$ & $-0.15^{*}$ & $-0.17 * *$ & $-0.14 *$ & -0.09 & INFL & 0.06 & -0.00 & -0.06 & -0.15 & $-0.22 * *$ \\
\hline \multicolumn{7}{|c|}{ Belgium } & \multicolumn{5}{|c|}{ Japan } \\
\hline RF & $-0.45 * * *$ & $-0.60 * * *$ & $-0.65 * * *$ & $-0.69 * * *$ & $-0.76 * * *$ & $\mathrm{RF}$ & 0.03 & 0.03 & 0.03 & 0.05 & 0.09 \\
\hline GDP & -0.01 & -0.15 & -0.08 & $-0.27^{*}$ & $-0.32 * *$ & GDP & $-0.15 *$ & $-0.19 * *$ & $-0.22 * * *$ & $-0.29 * * *$ & $-0.32 * * *$ \\
\hline GROWTH & 0.18 & 0.24 & 0.25 & 0.24 & 0.17 & GROWTH & $-0.16 * *$ & $-0.20 * * *$ & $-0.21 * * *$ & $-0.27 * * *$ & $-0.30 * * *$ \\
\hline LEV & 0.10 & $0.17^{*}$ & $0.17^{*}$ & $0.19 * *$ & $0.21^{* *}$ & LEV & -0.10 & $-0.14 *$ & $-0.19 * *$ & $-0.32 * * *$ & $-0.39 * * *$ \\
\hline POP & 0.07 & 0.11 & 0.11 & 0.13 & 0.15 & POP & -0.09 & -0.13 & $-0.16 * *$ & $-0.26 * * *$ & $-0.26 * * *$ \\
\hline INFL & $0.51 * * *$ & -0.04 & $0.31 * * *$ & -0.03 & -0.03 & INFL & $0.24 * * *$ & $0.51 * * *$ & $0.70 * * *$ & 0.01 & 0.01 \\
\hline \multicolumn{7}{|c|}{ Canada } & \multicolumn{5}{|c|}{ Netherlands } \\
\hline $\mathrm{RF}$ & -0.11 & $-0.14^{*}$ & $-0.17 * *$ & $-0.20 * *$ & $-0.15 *$ & $\mathrm{RF}$ & $-0.52 * * *$ & $-0.58 * * *$ & $-0.55 * * *$ & $-0.52 * * *$ & $-0.44 * * *$ \\
\hline GDP & -0.07 & -0.07 & -0.07 & -0.08 & $-0.15 *$ & GDP & $-0.40 * * *$ & $-0.48 * * *$ & $-0.52 * * *$ & $-0.57 * * *$ & $-0.70 * * *$ \\
\hline GROWTH & -0.09 & -0.10 & -0.10 & -0.12 & $-0.19 * *$ & GROWTH & $-0.48 * * *$ & $-0.58 * * *$ & $-0.62 * * *$ & $-0.67 * * *$ & $-0.77 * * *$ \\
\hline LEV & -0.04 & -0.05 & -0.05 & -0.06 & $-0.13 *$ & LEV & -0.07 & -0.05 & -0.04 & -0.03 & -0.02 \\
\hline POP & -0.09 & -0.11 & -0.11 & -0.13 & $-0.20 * * *$ & POP & $0.23 * * *$ & $0.30 * * *$ & $0.34 * * *$ & $0.37 * * *$ & $0.43 * * *$ \\
\hline INFL & -0.04 & -0.07 & -0.07 & -0.05 & -0.02 & INFL & $-0.21^{* *}$ & $-0.23 * * *$ & $-0.24 * * *$ & $-0.27 * * *$ & $-0.28 * * *$ \\
\hline \multicolumn{7}{|c|}{ Denmark } & \multicolumn{5}{|c|}{ Spain } \\
\hline $\mathrm{RF}$ & $-0.17 * *$ & $-0.16^{*}$ & $-0.17 *$ & $-0.16 *$ & $-0.21^{* *}$ & $\mathrm{RF}$ & 0.00 & -0.02 & -0.04 & -0.05 & -0.09 \\
\hline GDP & 0.08 & 0.07 & 0.07 & 0.06 & 0.04 & GDP & $-0.50 * * *$ & $-0.58 * * *$ & $-0.62 * * *$ & $-0.65 * * *$ & $-0.70 * * *$ \\
\hline GROWTH & 0.08 & 0.08 & 0.09 & 0.10 & $0.15^{*}$ & GROWTH & $-0.66 * * *$ & $-0.68 * * *$ & $-0.70 * * *$ & $-0.73 * * *$ & $-0.80 * * *$ \\
\hline LEV & -0.11 & -0.12 & -0.13 & -0.13 & -0.09 & LEV & $-0.28 * * *$ & $-0.31 * * *$ & $-0.32 * * *$ & $-0.33 * * *$ & $-0.34 * * *$ \\
\hline POP & 0.03 & 0.03 & 0.04 & 0.04 & 0.08 & POP & -0.11 & -0.10 & -0.09 & -0.08 & -0.07 \\
\hline INFL & 0.09 & -0.05 & -0.03 & -0.12 & -0.10 & INFL & $0.17 * *$ & $0.15^{*}$ & $0.14^{*}$ & $0.13 *$ & 0.03 \\
\hline \multicolumn{7}{|c|}{ Finland } & \multicolumn{5}{|c|}{ Sweden } \\
\hline RF & $-0.18 * *$ & $-0.23 * * *$ & $-0.23 * * *$ & $-0.24 * * *$ & $-0.21 * *$ & $\mathrm{RF}$ & $-0.27 * * *$ & $-0.47 * *$ & $-0.55 * * *$ & $-0.67 * * *$ & $-0.65 * * *$ \\
\hline GDP & -0.17 & $-0.25 *$ & -0.23 & -0.22 & -0.23 & GDP & $-0.44 * * *$ & $-0.48 * * *$ & $-0.51 * * *$ & $-0.44 * * *$ & $-0.47 * * *$ \\
\hline GROWTH & $0.25 *$ & 0.15 & 0.13 & 0.07 & 0.16 & GROWTH & $-0.52 * * *$ & $-0.34 * *$ & $-0.56 * * *$ & -0.04 & -0.03 \\
\hline LEV & $-0.14 *$ & $-0.19 * * *$ & $-0.22 * * *$ & $-0.26 * * *$ & $-0.33 * * *$ & LEV & -0.00 & 0.01 & 0.00 & 0.01 & -0.05 \\
\hline POP & 0.01 & 0.01 & 0.01 & 0.02 & -0.01 & POP & $0.21 * *$ & $0.34 * * *$ & $0.41 * * *$ & $0.50 * * *$ & $0.54 * * *$ \\
\hline INFL & $0.32 * * *$ & $0.16^{* *}$ & $0.26 * * *$ & 0.00 & -0.02 & INFL & $0.37 * * *$ & $0.28 * * *$ & $0.47 * * *$ & -0.10 & -0.13 \\
\hline \multicolumn{7}{|c|}{ France } & \multicolumn{5}{|c|}{ UK } \\
\hline $\mathrm{RF}$ & $-0.35 * * *$ & $-0.42 * * *$ & $-0.47 * * *$ & $-0.52 * * *$ & $-0.62 * * *$ & $\mathrm{RF}$ & $-0.14^{*}$ & $-0.15 *$ & $-0.15 *$ & $-0.15 *$ & -0.10 \\
\hline GDP & $-0.52 * * *$ & $-0.60 * * *$ & $-0.65 * * *$ & $-0.70 * * *$ & $-0.77 * * *$ & GDP & -0.02 & -0.03 & -0.04 & -0.05 & -0.06 \\
\hline GROWTH & $-0.55 * * *$ & $-0.60 * * *$ & $-0.65 * * *$ & $-0.68 * * *$ & $-0.76 * * *$ & GROWTH & -0.01 & -0.02 & -0.03 & -0.04 & -0.05 \\
\hline LEV & $-0.16^{* *}$ & $-0.19 * *$ & $-0.22 * * *$ & $-0.26 * * *$ & $-0.39 * * *$ & LEV & -0.09 & -0.11 & -0.12 & -0.12 & $-0.13 *$ \\
\hline POP & 0.13 & 0.13 & 0.13 & 0.13 & $0.19 * *$ & POP & -0.08 & -0.08 & -0.09 & -0.10 & -0.11 \\
\hline INFL & $-0.19 * *$ & $-0.21^{* * *}$ & $-0.22 * * *$ & $-0.22 * * *$ & $-0.24 * * *$ & INFL & $-0.20 * * *$ & $-0.22 * * *$ & $-0.25 * * *$ & $-0.25 * * *$ & $-0.27 * * *$ \\
\hline & & & Germany & & & & & & US & & \\
\hline $\mathrm{RF}$ & 0.00 & -0.03 & -0.07 & -0.12 & $-0.28 * * *$ & $\mathrm{RF}$ & $-0.18 * *$ & $-0.22 * * *$ & $-0.27 * * *$ & $-0.32 * * *$ & $-0.40 * * *$ \\
\hline GDP & 0.12 & 0.13 & 0.14 & 0.14 & $0.31 *$ & GDP & -0.06 & -0.07 & -0.07 & -0.07 & -0.05 \\
\hline GROWTH & 0.18 & 0.22 & 0.21 & 0.22 & $0.41 * * *$ & GROWTH & -0.07 & -0.07 & -0.07 & -0.06 & -0.03 \\
\hline LEV & -0.04 & -0.07 & -0.07 & -0.08 & -0.08 & LEV & -0.10 & -0.10 & -0.10 & -0.10 & -0.08 \\
\hline POP & 0.01 & 0.01 & 0.03 & 0.03 & 0.05 & POP & -0.10 & -0.11 & -0.10 & -0.09 & -0.03 \\
\hline INFL & 0.12 & 0.11 & 0.11 & 0.09 & 0.07 & INFL & -0.11 & $-0.14 *$ & $-0.19 * *$ & $-0.23 * * *$ & $-0.33 * * *$ \\
\hline & & & Italy & & & & & & & & \\
\hline RF & $0.29 * * *$ & $0.32 * * *$ & $0.33 * * *$ & $0.33 * * *$ & $0.33 * * *$ & & & & & & \\
\hline GDP & $-0.29 *$ & $-0.43 * * *$ & $-0.50 * * *$ & $-0.57 * * *$ & $-0.72 * * *$ & & & & & & \\
\hline GROWTH & $-0.55 * * *$ & $-0.62 * * *$ & $-0.66 * * *$ & $-0.70 * * *$ & $-0.76 * * *$ & & & & & & \\
\hline LEV & $-0.59 * * *$ & $-0.67 * * *$ & $-0.69 * * *$ & $-0.70 * * *$ & $-0.70 * * *$ & & & & & & \\
\hline POP & $-0.68 * * *$ & $-0.78 * * *$ & $-0.81 * * *$ & $-0.83 * * *$ & $-0.86 * * *$ & & & & & & \\
\hline INFL & $0.44 * * *$ & $0.41 * * *$ & $0.42 * * *$ & $0.44 * * *$ & $0.30 * *$ & & & & & & \\
\hline
\end{tabular}

Notes: $*{ }^{* *}, * * *$ denote statistical significance at the 10,5 , and $1 \%$ level, respectively. 
Table 13 - Predictability of real housing returns (using cay) and country characteristics - Evidence from pooled regressions.

\begin{tabular}{lccccc}
\hline \multirow{2}{*}{ Regressor } & \multicolumn{5}{c}{ Forecast Horizon $H$} \\
\cline { 2 - 6 } RF & 1 & 2 & 3 & 4 & 8 \\
& $0.0011^{* *}$ & $0.0016^{* *}$ & $0.0019 * *$ & 0.0011 & $0.0023^{* * *}$ \\
& $(2.447)$ & $(2.413)$ & $(2.484)$ & $(1.329)$ & $(2.719)$ \\
GDP & {$[0.004]$} & {$[0.004]$} & {$[0.004]$} & {$[0.001]$} & {$[0.004]$} \\
& $-0.0043^{* * *}$ & $-0.0034^{* * *}$ & $0.0024^{* *}$ & $0.0244^{* * *}$ & $-0.0141^{* * *}$ \\
& $(-7.471)$ & $(-4.010)$ & $(2.351)$ & $(19.531)$ & $(-9.314)$ \\
GROWTH & {$[0.004]$} & {$[0.001]$} & {$[0.00]$} & {$[0.025]$} & {$[0.005]$} \\
& $-0.036 * * *$ & $-0.065^{* * *}$ & $-0.006^{* * *}$ & -0.0011 & $-0.0149 * * *$ \\
LEV & $(-10.487)$ & $(-11.576)$ & $(-8.745)$ & $(-1.215)$ & $(-16.350)$ \\
& {$[0.021]$} & {$[0.031]$} & {$[0.019]$} & {$[0.00]$} & {$[0.051]$} \\
& $0.0001^{* * *}$ & 0.00 & $0.0001^{*}$ & $0.0002 * * *$ & $-0.0002^{* * *}$ \\
POP & $(2.723)$ & $(1.107)$ & $(1.775)$ & $(2.893)$ & $(-2.635)$ \\
& {$[0.002]$} & {$[0.00]$} & {$[0.001]$} & {$[0.002]$} & {$[0.002]$} \\
& 0.00 & $0.00 * * *$ & 0.00 & $-0.0000^{*}$ & $-0.0000^{* * *}$ \\
INFL & $(-0.478)$ & $(2.666)$ & $(-0.631)$ & $(-1.934)$ & $(-4.147)$ \\
& {$[0.00]$} & {$[0.0023]$} & {$[0.00]$} & {$[0.001]$} & {$[0.05]$} \\
& $0.0017 * * *$ & $0.0023^{* * *}$ & $0.0029 * * *$ & $0.0029 * * *$ & $0.0031^{* * *}$ \\
& $(4.116)$ & $(3.855)$ & $(4.411)$ & $(4.033)$ & $(3.664)$ \\
& {$[0.004]$} & {$[0.003]$} & {$[0.004]$} & {$[0.003]$} & {$[0.003]$} \\
\hline
\end{tabular}

Notes: The table reports pooled OLS regressions across our sample of 15 countries. The dependent variable is the $\mathrm{R}^{2}$ of the individual forecasting regressions using cay as the predictor. The explanatory variable is a specific country characteristic. Robust $t$-statistics appear in parenthesis. 


\section{List of Figures}

Figure 1a - Panel correlation between real housing returns (at different time horizons) and country characteristics (risk-free rate and real GDP per capita).

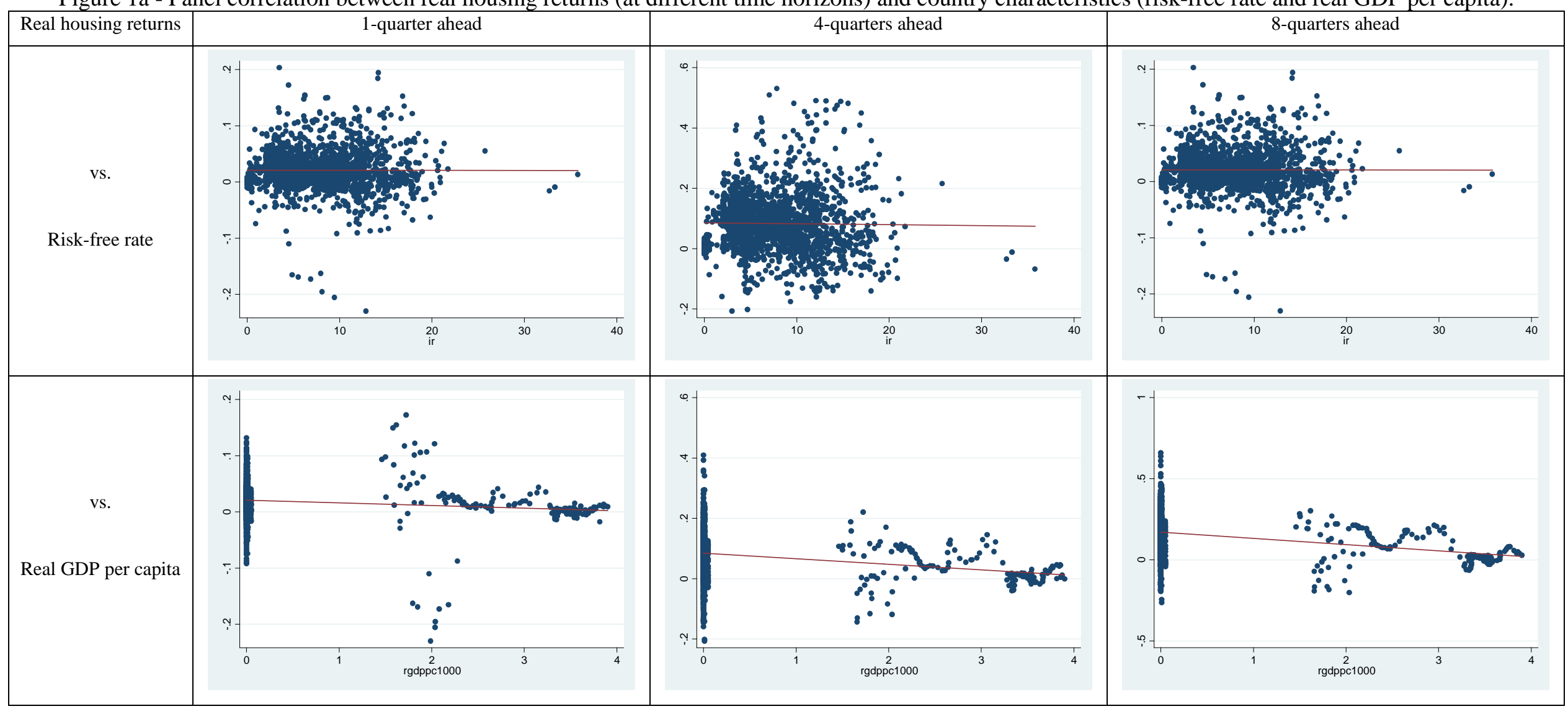


Figure 1b - Panel correlation between real housing returns (at different time horizons) and country characteristics (real GDP growth rate and leverage ratio).

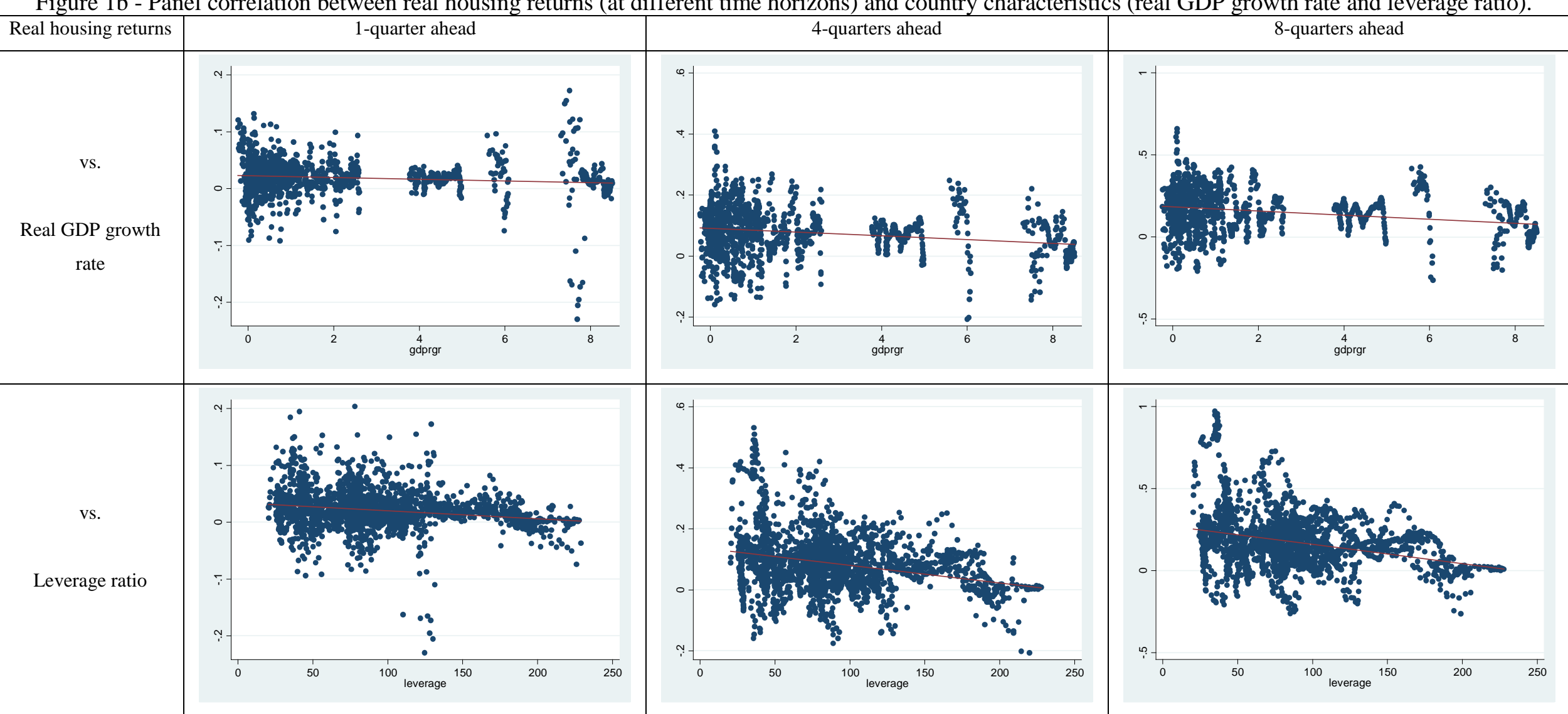


Figure 1c - Panel correlation between real housing returns (at different time horizons) and country characteristics (population and inflation).

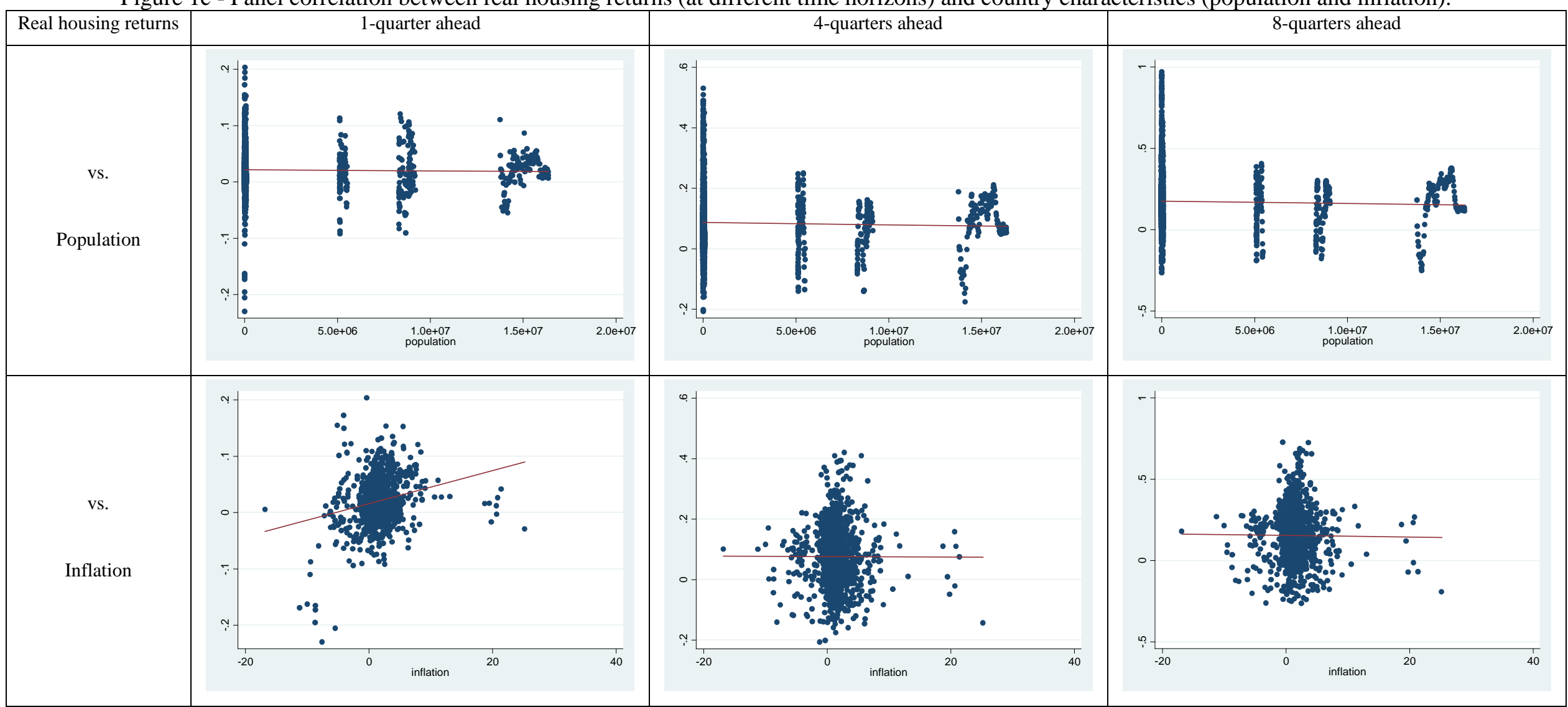

